\title{
Rises, Trenches, Great Faults, and Crustal Blocks ${ }^{1}$
}

\author{
W. JASON MORGaN \\ Department of Geology, Princeton University, Princeton, New Jersey 08540 \\ and Department of Geology and Geophysics, Woods Hole Oceanographic Institution \\ Woods Hole, Massachusetts 02548
}

\begin{abstract}
The transform fault concept is extended to a spherical surface. The earth's surface is considered to be made of a number of rigid crustal blocks. It is assumed that each block is bounded by rises (where new surface is formed), trenches or young fold mountains (where surface is being destroyed), and great faults, and that there is no stretching, folding, or distortion of any. kind within a given block. On a spherical surface, the motion of one block (over the mantle) relative to another block may then be described by a rotation of one block relative to the other block. This rotation requires three parameters, two to locate the pole of relative rotation and one to specify, the magnitude of the angular velocity. If two adjacent blocks have as common boundaries a number of great faults, all of these faults must lie on 'circles of latitude' about the pole of relative rotation. The velocity of one block relative to the other must vary along their common boundary; this velocity would have a maximum at the 'equator' and would vanish at a pole of relative rotation.

The motion of Africa relative to South America is a case for which enough data are available to critically test this hypothesis. The many offsets on the mid-Atlantic ridge appear to be compatible with a pole of relative rotation at $62^{\circ} \mathrm{N}\left( \pm 5^{\circ}\right), 36^{\circ} \mathrm{W}\left( \pm 2^{\circ}\right)$. The velocity pattern predicted by this choice of pole roughly agrees with the spreading velocities determined from magnetic anomalies. The motion of the Pacific block relative to North America is also examined. The strike of faults from the Gulf of California to Alaska and the angles inferred from earthquake mechanism solutions both imply a pole of relative rotation at $53^{\circ} \mathrm{N}\left( \pm 3^{\circ}\right), 53^{\circ} \mathrm{W}\left( \pm 5^{\circ}\right)$. The spreading of the Pacific-Antarctic ridge shows the best agreement with this hypothesis. The Antarctic block is found to be moving relative to the Pacific block about a pole at $71^{\circ} \mathrm{S}\left( \pm 2^{\circ}\right), 118^{\circ} \mathrm{E}\left( \pm 5^{\circ}\right)$ with a maximum spreading rate of 5.7 $( \pm 0.2) \mathrm{cm} / \mathrm{yr}$. An estimate of the motion of the Antarctic block relative to Africa is made by assuming closure of the Africa-America-Pacific-Antarctica-Africa circuit and summing the three angular velocity vectors for the cases above.
\end{abstract}

\section{INTRODUCTION}

A geometrical framework with which to describe present day continental drift is presented here. This presentation is an extension of the transform fault concept [Wilson, 1965] to a spherical surface. The surface of the earth is divided into about twenty units, or blocks, as shown in Figure 1. Some of these blocks are of continental dimensions (the Pacific block and the African block); some are of sub-continental dimensions (the Juan de Fuca block, the Caribbean block, and the Persian block). The boundaries between blocks are of three types and are determined by present day tectonic activity. The first boundary is the rise type at which new crustal material is being formed. The second

\footnotetext{
${ }^{1}$ Woods Hole Oceanographic Institution Contribution 1984.
}

boundary is the trench type at which crustal surface is being destroyed; that is, the distance between two landmarks on opposite sides of a trench gradually decreases and at least one of the landmarks will eventually disappear into the trench floor. Other compressive systems in which the distance between two points decreases and the crust thickens, e.g., the folded mountains north of the Persian Gulf, are considered to be of this second type. The third boundary is the fault type at which crustal surface is neither created nor destroyed. Each block in Figure 1 is surrounded by some combination of these three types of boundaries. For example, Arabia is separated from Africa by the AdenRed Sea rise and fracture zone system and by the Aqaba-Dead Sea fault. Arabia is separated from the Indian-Australian block by the Owen fracture zone (considered to be a transcurrent fault), and it is separated from Persia and from 


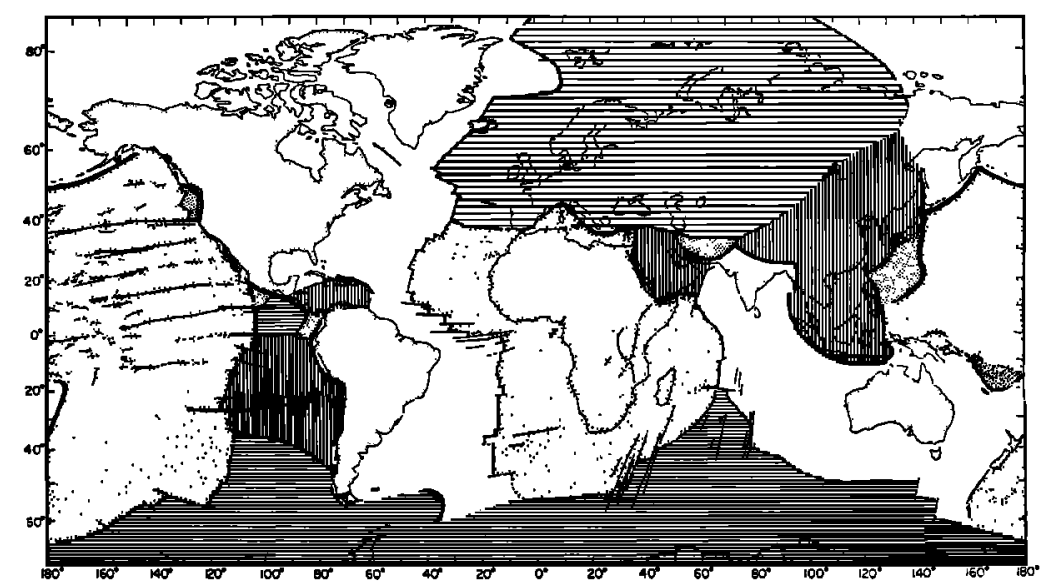

Fig. 1. The crust is divided into units that move as rigid blocks. The boundaries between blocks are rises, trenches (or young fold mountains), and faults. The boundaries drawn in Asia are tentative, and additional sub-blocks may be required. (Figure is based on Sykes's [1968b] map of the ridge system with additional features from Heezen and Tharp's [1965] tectonic map.)

Europe by the compressive-type features in Iran and Turkey.

The compressive-type boundary seems to be the most difficult to delineate. The Tonga-New Zealand-Macquarie system has the well-developed Tonga trench at its northern end and the anomalous Macquarie ridge at its southern end. We suppose that this ridge is the result of slow compression and that fast compression leads to the trench-type structure. (In the terminology used here, the pole of rotation of the Pacific block relative to the Indian-Australian block is located near the southern end of the Macquarie ridge.) This results in a slow rate of closing along the Macquarie ridge (near the pole) and a fast closing of the Tonga trench and an equally fast slipping along the fault between New Guinea and the Fiji Islands. We have supposed that slow compressive systems are difficult to identify and have freely placed such boundaries at likely places. For example, a compressive-type boundary has been placed in the Mediterranean Sea between Europe and Africa. There might, in fact, be two almost parallel compressive belts in this region with a series of sub-blocks between them: the western Mediterranean, the Balkans, and others. The boundaries in the complex area around Central America are based on linear belts of earthquakes, and it is believed this subdivision is correct. The area east of New Guinea is less certain; it is believed that there is a fault between New Guinea and Fiji primarily accommodating the westward motion of the Pacific block and that there is a trench just south of this fault primarily accommodating the northward motion of the Indian-Australian block. The boundaries in Siberia and Central Asia are very uncertain. There is no compelling reason to separate China from the North American block. The Ninetyeast ridge between India and Australia and the mid-Labrador Sea ridge between Greenland and North America are probably fossil boundaries.

We now make the assumption that gives this model mathematical rigor. We assume that each crustal block is perfectly rigid. If the distances between Guadalupe Island, Wake Island, and Tahiti, all within the Pacific block, were measured to the nearest centimeter and then measured again several years later, we suppose these distances would not change. The distance from Wake Island to Tokyo would, however, shorten because there is a trench between these two points, and the distance from Guadalupe Island to Mexico City would increase because there is a rise between these two points. But within the Pacific block, or any other crustal block, we shall assume there is no stretching, injection of large dikes, thickening, or any other distortion that would change distances between points. If this hypothesis is true, our conclusions 
will be in accord with observation. If this hypothesis is only partially valid, perhaps we will be able to assess the extent of such distortion by comparing observations with this model.

As will be demonstrated later (see Figure 4), the relative motion between two blocks may be represented by an angular velocity vector. Suppose the velocity of North America relative to Africa is $\omega_{\mathrm{Am}-\mathrm{Af}}$ and the velocity of the Pacific relative to North America is $\omega_{\mathrm{Pac}_{\mathrm{am}} \mathrm{Am}}$. We may find the velocity of the Pacific relative to Africa by vector addition; $\omega_{P_{a 0}-A}=\omega_{P_{a 0}-A m}+$ $\omega_{\text {Am-Af }}$. We may also find the angular velocity of the Pacific relative to Africa by another route: first Africa to Antarctica and then Antarctica to the Pacific. Will the $\omega_{\mathrm{Pa}-A f}$ so found equal that found via the other route? It is not believed the hypothesis of rigidity would rigorously meet this test. Such features as the African rift eystem, the Cameroon trend, and the Nevada-Utah earthquake belt are most likely the type of distortion denied in the rigidity hypothesis. Nevertheless, it is of interest to see how far this simplying concept of rigidity can be applied.

We begin by considering blocks sliding on a plane. In this simple case we ignore the possibility of rotations and consider translations only. Figure 2 shows two rigid blocks separated by a rise and faults. From the rise alone, we cannot tell the direction of motion of one block relative to the other; the motion does not have to be perpendicular to the axis of the ridge. (There appears to be a tendency for the ridge to adjust itself to be almost perpendicular to the direction of spreading, but this is a dynamical consideration and not a requirement of geometry.) From the direction of a single transform fault, however, we can decide upon the direction of relative motion of the two blocks. The fault shown at the bottom of Figure 2 is incompatible with the two faults above and would not occur. The magnetic anomaly pattern (which will be parallel to the ridge crest) may now be projected along a line parallel to the direction of relative motion, and the velocity of one block relative to the other may be determined from the spacing of the anomalies.

Figure 3 shows three blocks separated by. a trench, a rise, and two faults at three successive time intervals. The blocks have velocities relative to our coordinate system as shown in the figure for time 1 . The four circles in this figure represent circular markers placed on the sea floor. At times 2 and 3, these markers have moved according to the velocity of their respective block (their original coordinates are shown by the dotted circles). We see that the strike of an offset depends on the difference between the velocities of the two sides. The active segment between the offsets of the ridge crest, and the extensions of this fracture zone, will have the same strike out to a distance that corresponds to the time interval during which the velocity difference of the two blocks has had its present azimuth. Further, we see that, if the ridge pattern remains symmetric, the axis of the ridge will have a 'drift' velocity equal to the

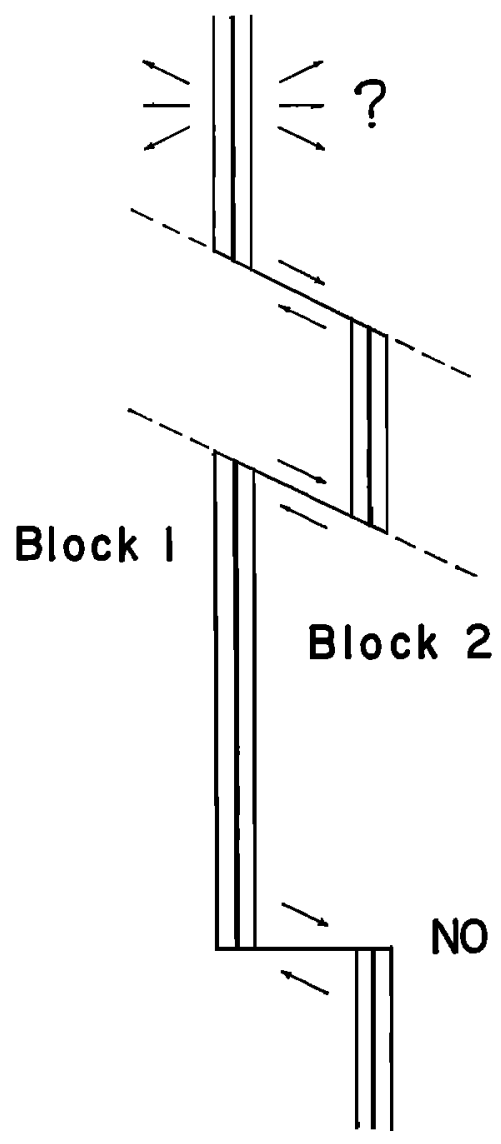

Fig. 2. The motion of the left-hand block relative to the right-hand block cannot be determined from the strike of the ridge, but it can be determined from the strike of the transform faults. The fault at the bottom has a strike inconsistent with the other two faults and should not co-exist with them. 


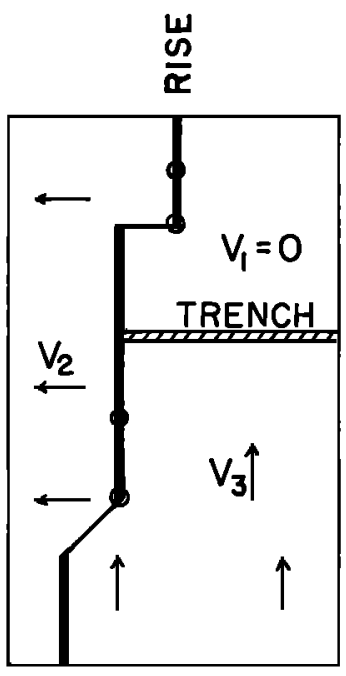

Time 1
$\frac{\vec{W}}{\tilde{x}}$

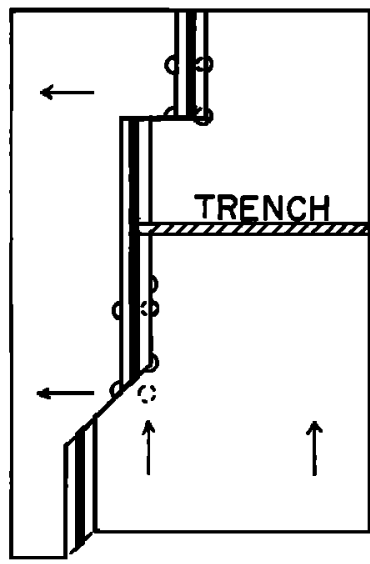

Time 2 $\frac{\omega}{\mathbb{x}}$

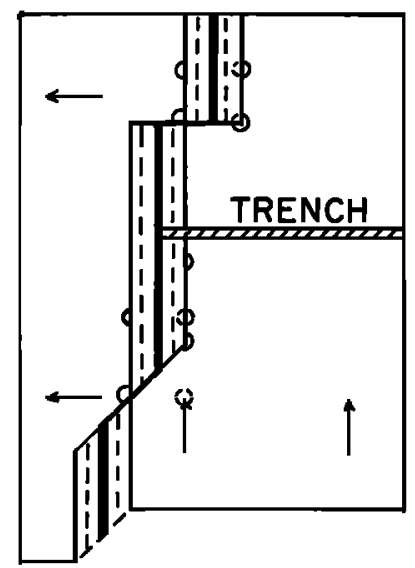

Time 3

Fig. 3. Three crustal blocks bounded by a rise, trench, and faults are shown at three successive time intervals. Note the motion of the four circular markers placed on the ridge crest at time 1: the solid segments show the motion of these circles; the dotted segments show the original coordinates of these markers. The strike of a transform fault is parallel to the difference of the velocities of the two sides; the crest of the ridge drifts with a velocity that is the average of the velocities of the two sides.

vector average of the velocities of the two sides. Note that the two transform faults extending into block 2 on the left are not parallel. All faults north of the trench (between blocks 1 and 2) would run east to west as the one shown, and all faults south of the trench (between blocks 2 and 3) would have a $45^{\circ}$ strike as shown. An example of where the strike of transform faults changes in this manner occurs off the coast of Mexico at the intersection of the Middle America trench, the East Pacific rise, and the Gulf of California.

We now go to a sphere. A theorem of geometry states that a block on a sphere can be moved to any other conceivable orientation by a single rotation about a properly chosen axis. We use this theorem to prove that the relative motion of two rigid blocks on a sphere may be described by an angular velocity vector by using three parameters, two to specify the location of the pole and one for the magnitude of the angular velocity. Consider the left block in Figure 4 to be stationary and the right block to be moving as shown. Fault lines of great displacement occur where there is no component of velocity perpendicular to their strike; the strike of the fault must be parallel to the difference in velocity of the two sides. Thus, all the faults common to these two blocks must lie on small circles concentric about the pole of relative moton.

The velocity of one block relative to another will vary along their common boundary; this

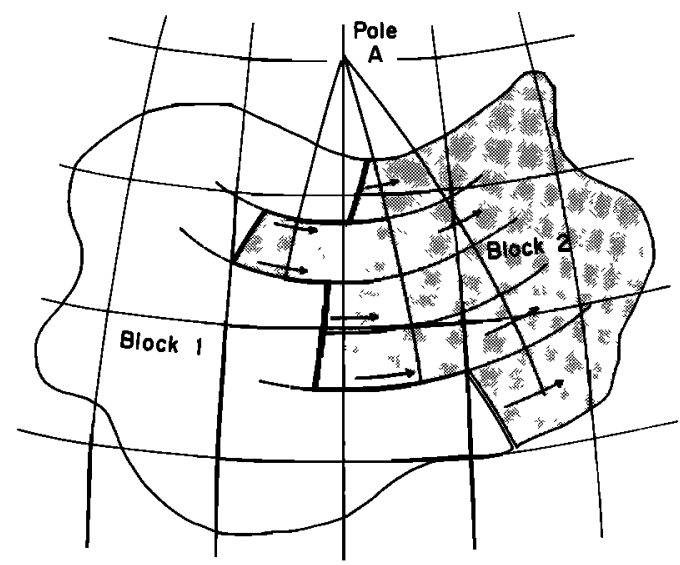

Fig. 4. On a sphere, the motion of block 2 relative to block 1 must be a rotation about some pole. All faults on the boundary between 1 and 2 must be small circles concentric about the pole $\mathrm{A}$. 
velocity has a maximum at the 'equator' and vanishes at the poles of rotation. It is convenient to let the 'half-velocity perpendicular to the strike of the ridge' be the form in which the observations are placed. We choose 'halfvelocity' since this is the form in which sea floor spreading rates are commonly quoted. There appears to be some self-adjusting mechanism in the rifting process that gives rise to a symmetric magnetic anomaly pattern, but there is no geometrical requirement that spreading rates be equal on both sides. To allow for the possibility of unequal rates on the two sides of a ridge, we define half-velocity to be half the distance from a recognizable feature of the magnetic pattern to the corresponding feature on the other side of the ridge divided by the appropriate time. We choose 'perpendicular to the strike of the ridge' since this means an observed rate need be determined only once, and this value is then compared to a choice of models calculated with different pole positions and angular velocities. The angular relations used to project a pattern of magnetic anomalies from a ship's track to a line perpendicular to the strike of the ridge are shown in Figure 5. If we know the latitude and longitude of a point on the crest of the ridge, and if we know the strike of the ridge at this point, we calculate the velocity of spreading perpendicular to the strike of the ridge according to

$$
\begin{aligned}
\theta= & \operatorname{arcos}[\sin (R L A T) \sin (P L A T)+ \\
& \cos (R L A T) \cos (P L A T) \cos (P L O N G \\
& -R L O N G)] \\
\alpha= & \operatorname{arsin}[\sin (P L O N G-\operatorname{RLONG}) \\
& \cos (P L A T) / \sin \theta] \\
V_{\perp}= & V_{\max } \sin \theta \cos (\text { STRIKE }-\alpha)
\end{aligned}
$$

The quantities used in these formulas are shown in Figure 6.

\section{The Motion of the African Block Relative to The South American Block}

Figure 7 shows the offsets of the ridge in the equatorial Atlantic Ocean. A set of circles concentric about a pole at $58^{\circ} \mathrm{N}, 36^{\circ} \mathrm{W}$ is plotted on a figure of Heezen and Tharp [1965]. Figure $8 a$ shows how this pole position was obtained. Great circles were constructed perpendicular to the strike of each fracture zone offsetting the crest of the ridge listed in Table 1 . The intersec-

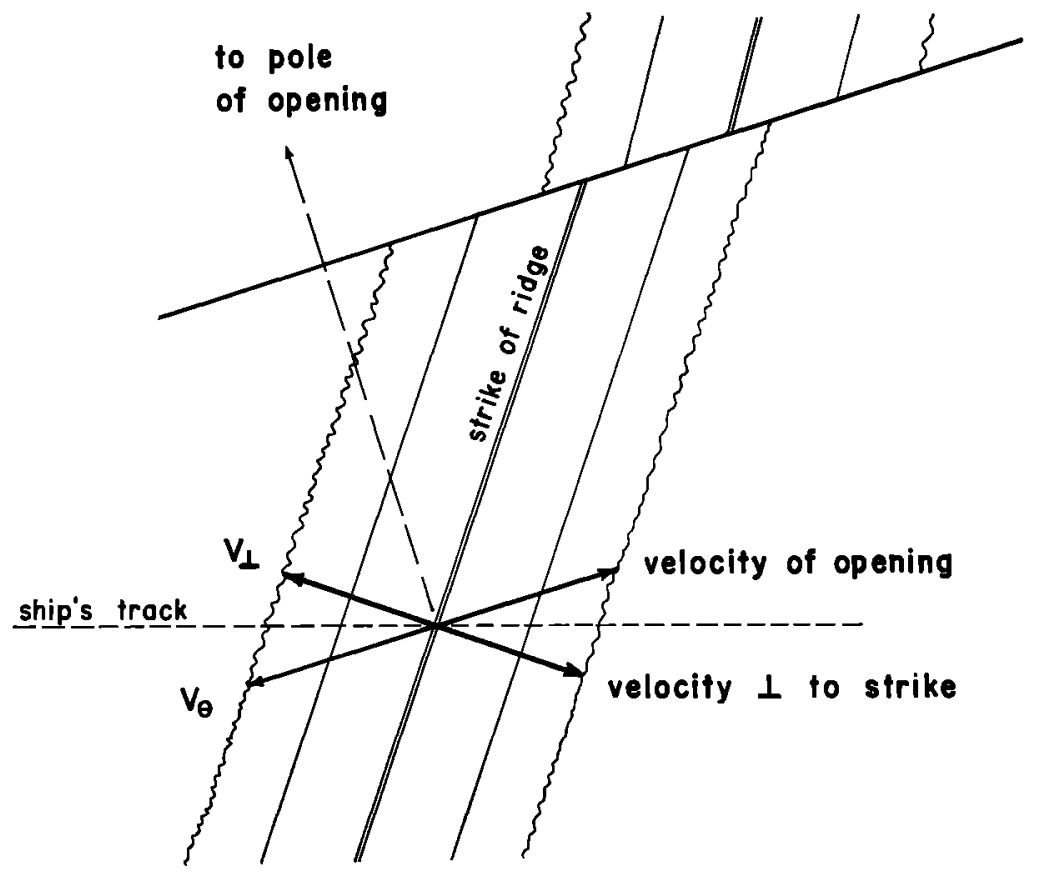

Fig. 5. The magnetic profile measured along the ship's track must be projected parallel to the strike of the ridge. 


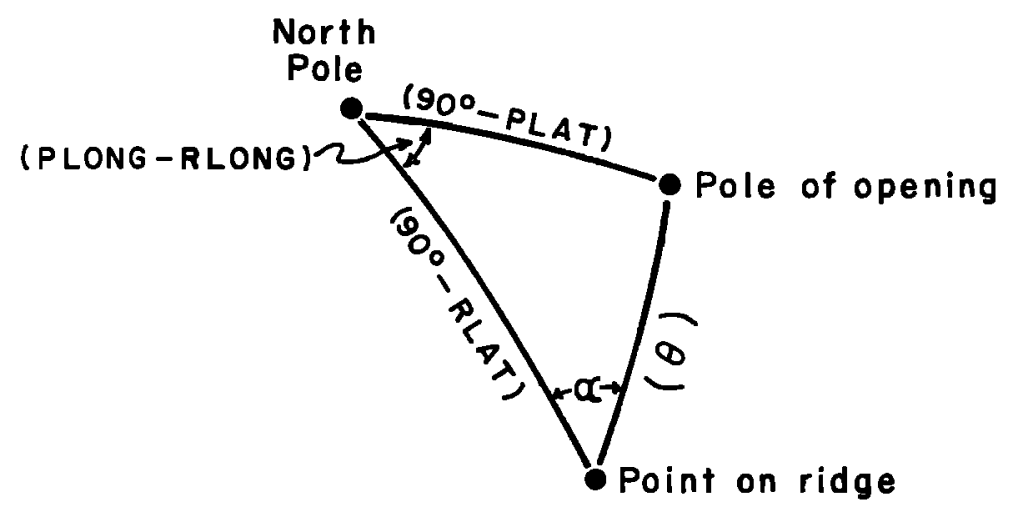

Fig. 6. The angular relations used in deriving the formula for spreading velocity.

tions of the great circles define the pole of rotation; the great circles are analogous to meridians and the fault lines are analogous to lines of latitude about this pole. As we see in Figure 8, the perpendiculars intersect at grazing angles and give good control in longitude but poor control in latitude. All of the perpendiculars except the one constructed for the fracture zone at $14.5^{\circ} \mathrm{N}$ pass through the circle drawn in the figure, $57.5^{\circ} \mathrm{N}\left( \pm 2^{\circ}\right), 36.5^{\circ} \mathrm{W}\left( \pm 4^{\circ}\right)$. Several other circles of about the same radius, which included all the perpendiculars except perhaps two or three, were also drawn. The centers of these circles ranged from $51^{\circ} \mathrm{N}$ to $63^{\circ} \mathrm{N}$ and from $35^{\circ} \mathrm{W}$ to $38^{\circ} \mathrm{W}$. The limits on the location of the pole of rotation by this method are estimated to be $58^{\circ} \mathrm{N}\left( \pm 5^{\circ}\right), 36^{\circ} \mathrm{W}\left( \pm 2^{\circ}\right)$.

The strikes of transcurrent earthquakes used in Figure $8 b$ are listed in Table 2. The common intersection in Figure $8 b$ is not so good as the intersection in Figure 8a. It is interesting that a circle of about $6^{\circ}$ radius can be used both here and in the Pacific-North America case (see Figure $14 f$ ) to illustrate the departure from a point intersection. The bulk of the epicenters are about $45^{\circ}(5000 \mathrm{~km})$ from the point of intersection in both of these cases. This suggests that the accuracy to which the fault planes are determined, or the accuracy to which the first motions represent the strike of a long fault, is the cause of the scatter in Figures $8 b$ and $14 f$.

There is one fracture zone north of approximately $20^{\circ} \mathrm{N}$ listed in Table 1 ; there are two earthquake solutions north of this point listed in Table 2. This latitude roughly divides the ridge into a part between North America and Africa and a part between South America and Africa. There is no striking difference between

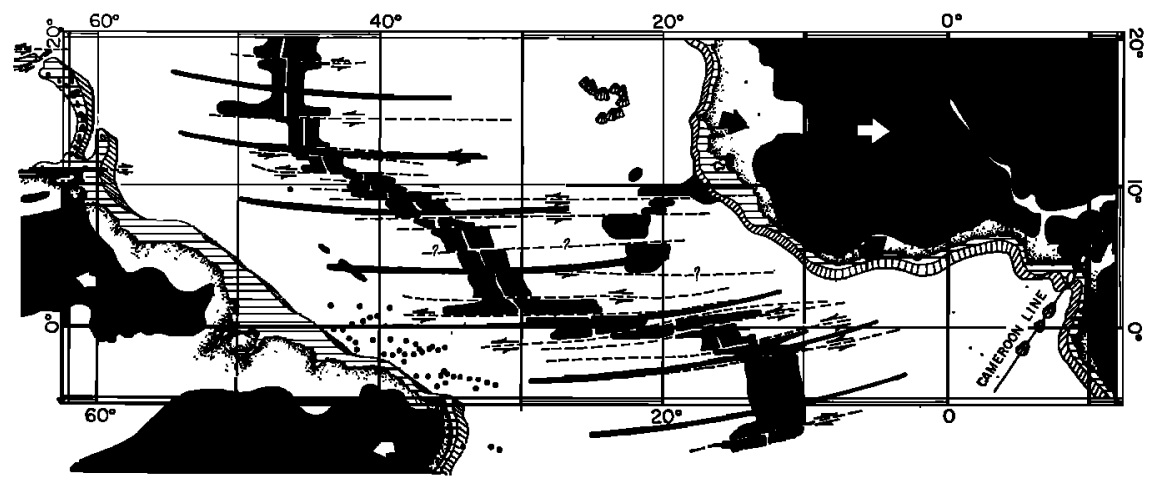

Fig. 7. The strike of the transform faults in the equatorial Atlantic are compared with circles concentric about a pole at $62^{\circ} \mathrm{N}, 36^{\circ} \mathrm{W}$. These circles indicate the present motion of Africa relative to South America. (Figure is adapted from Heezen and Tharp [1965].) 


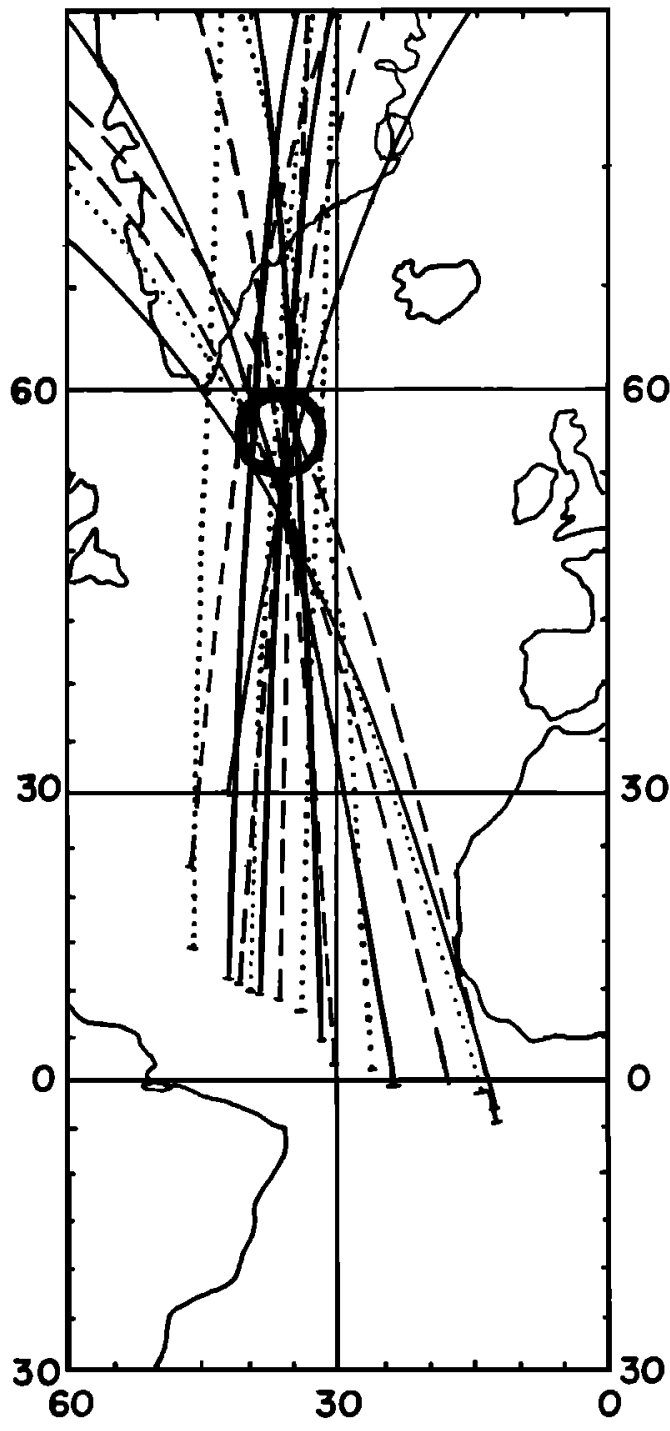

(a)

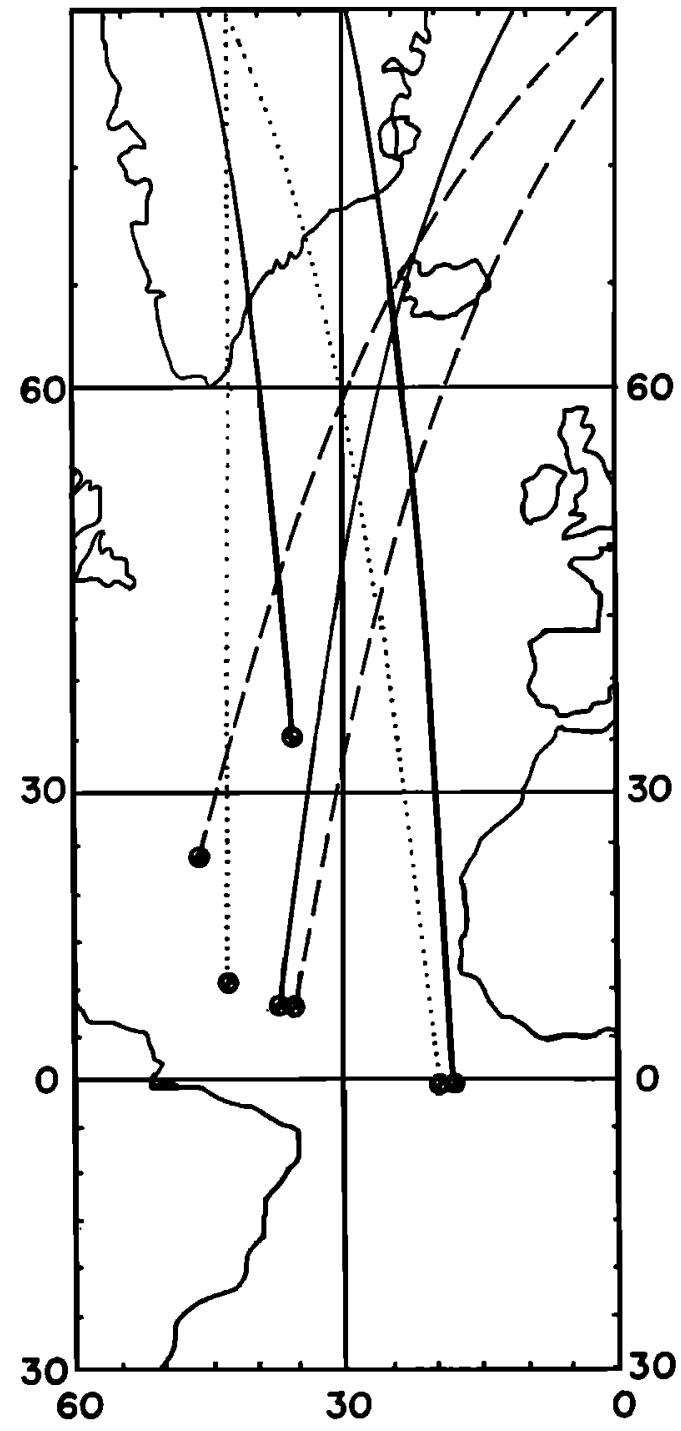

(b)

Fig. 8. Great circles perpendicular to the strike of offsets of the mid-Atlantic ridge are shown in (a). With one exception, all of these lines pass within the circle centered at $58^{\circ} \mathrm{N}$, $36^{\circ} \mathrm{W}$. Great circles perpendicular to the strike determined by earthquake mechanism solutions are shown in $(b)$.

these three values north of $20^{\circ} \mathrm{N}$ and those south of this latitude, and there is no line of earthquakes or other indication of tectonic activity entirely separating North America and South America. We shall assume that North America and South America at present move as a single block. The Caribbean area almost en- tirely separates the Americas, and perhaps there is a slow relative movement with gradual distortion in the Atlantic Ocean area. If there is relative movement, the velocities and displacements involved will be very slow at this 'hinge' or 'pole' somewhere between the Lesser Antilles and the mid-Atlantic ridge. In contrast, the 
TABLE 1. Strike of Faults on the Mid-Atlantic Ridge

\begin{tabular}{lcccc}
\hline Name & Latitude & $\begin{array}{c}\text { Longi- } \\
\text { tude }\end{array}$ & Strike & $\begin{array}{c}\text { Ref- } \\
\text { erence }\end{array}$ \\
\hline Atlantis & $30.0^{\circ} \mathrm{N}$ & $42.3^{\circ} \mathrm{W}$ & $99^{\circ}$ & $a$ \\
& $18.5^{\circ} \mathrm{N}$ & $46.8^{\circ} \mathrm{W}$ & $95^{\circ}$ & $a$ \\
& $14.5^{\circ} \mathrm{N}$ & $46.0^{\circ} \mathrm{W}$ & $91^{\circ}$ & $a$ \\
Vema V & $10.8^{\circ} \mathrm{N}$ & $42.3^{\circ} \mathrm{W}$ & $92^{\circ}$ & $b$ \\
Vema W & $10.2^{\circ} \mathrm{N}$ & $40.9^{\circ} \mathrm{W}$ & $94^{\circ}$ & $b$ \\
Vema X & $9.4^{\circ} \mathrm{N}$ & $40.0^{\circ} \mathrm{W}$ & $92^{\circ}$ & $b$ \\
Vema Y & $8.8^{\circ} \mathrm{N}$ & $38.7^{\circ} \mathrm{W}$ & $92^{\circ}$ & $b$ \\
Vema Z & $7.6^{\circ} \mathrm{N}$ & $36.6^{\circ} \mathrm{W}$ & $91^{\circ}$ & $b$ \\
& $7.2^{\circ} \mathrm{N}$ & $34.3^{\circ} \mathrm{W}$ & $91^{\circ}$ & $b$ \\
& $4.0^{\circ} \mathrm{N}$ & $31.9^{\circ} \mathrm{W}$ & $88^{\circ}$ & $c$ \\
St. Paul's & $1.9^{\circ} \mathrm{N}$ & $30.6^{\circ} \mathrm{W}$ & $86^{\circ}$ & $c$ \\
& $1.1^{\circ} \mathrm{N}$ & $26.0^{\circ} \mathrm{W}$ & $86^{\circ}$ & $c$ \\
Romanche & $1^{\circ} \mathrm{S}$ & $24.0^{\circ} \mathrm{W}$ & $81^{\circ}$ & $c$ \\
Chain & $1^{\circ} \mathrm{S}$ & $18.0^{\circ} \mathrm{W}$ & $77^{\circ}$ & $c$ \\
& $1.9^{\circ} \mathrm{S}$ & $14.5^{\circ} \mathrm{W}$ & $75^{\circ}$ & $c$ \\
& $2.9^{\circ} \mathrm{S}$ & $12.5^{\circ} \mathrm{W}$ & $82^{\circ}$ & $c$ \\
& $7^{\circ} 5^{\circ} \mathrm{S}$ & $12.3^{\circ} \mathrm{W}$ & $73^{\circ}$ & $c$ \\
& & & $a$ \\
\hline
\end{tabular}

a Heezen and Tharp [1965].

${ }^{b}$ Heezen et al. [1964b].

- Heezen et al. [1964a].

Azores-Gibraltar ridge is presumed to be a major transcurrent fault between the African and European blocks. All fracture zones north of the Azores are between Europe and America and have a different pole of opening.

Figure 9 shows several observed spreading rates in the Atlantic Ocean compared with the model. Since the ridge runs almost north-south with only a minimum of doubling back at the equator, latitude is a convenient coordinate against which to plot the rates. To use the preceding formulas for spreading rate, knowledge of the latitude, longitude, and strike of the ridge is needed at each point along the ridge. These quantities were obtained from figures in Talwani et al. [1961] (northern region), Heezen and Tharp [1965] (equatorial region), and Heirtzler and Le Pichon [1965] (southern region). The solid line in Figure 9 was calculated with these quantities and with the choice of $P L A T=$ $62^{\circ} \mathrm{N}, P L O N G=36^{\circ} \mathrm{W}, V_{\max }=1.8 \mathrm{~cm} / \mathrm{yr}$. The dashed line was calculated without the strike correction; it does not give the halfvelocity perpendicular to the strike of the ridge but, rather, it gives the half-velocity parallel to the direction of spreading.

This figure was originally calculated with
$P L A T=58^{\circ} \mathrm{N}$, the latitude of the center of the circle in Figure $8 a$. With this pole position the computed curve does not satisfactorily fit the observed points: the points south of $20^{\circ} \mathrm{S}$ alone fit $V_{\max }=1.8 \mathrm{~cm} / \mathrm{yr}$; the points north of $20^{\circ} \mathrm{N}$ better fit $V_{\max }=2.2 \mathrm{~cm} / \mathrm{yr}$. If the pole is chosen farther north, say at $62^{\circ} \mathrm{N}$ as shown in the figure, a single curve apparently fits both the northern and southern portions of the data within the scatter of the points. The velocity pattern is sensitive to the latitude but not the longitude of the chosen pole, whereas the intersection of the perpendiculars in Figure 8 was just the opposite. $A$ pole at $62^{\circ} \mathrm{N}\left( \pm 5^{\circ}\right)$, $36^{\circ} \mathrm{W}\left( \pm 2^{\circ}\right)$ with a maximum velocity of 1.8 $( \pm 0.1) \mathrm{cm} / \mathrm{yr}$ satisfies both of these criteria.

The observed spreading rates were inferred from magnetic profiles over the mid-Atlantic ridge in the following manner. The two points Chain 44 and Chain 61 were determined by Phillips [1967]. The magnetic profiles used for obtaining the other points may be found in Heirtzler and Le Pichon [1965], Talwani et al. [1961], Vacquier and Von Herzen [1964], and U. S. Naval Oceanographic Office [1965]. The strike of the ridge at the crossings of Vema 4, 17 , and 10 was assumed to be $38^{\circ}, 38^{\circ}$, and $30^{\circ}$, respectively. Zero strike was assumed at the crossings of Argo, Vema 18, Zapiola, Vema 12, and Project Magnet Flight 211. Simulated magnetic anomaly profiles at locations near each crossing of the ridge were calculated with the normal-reversed time scale (and computer program) of F. J. Vine (Vine [1966], fig. 12). The spreading rates were established by matching features on the computed profiles (known time) to corresponding features on the observed pro-

TABLE 2. Strikes Determined from Transcurrent Earthquakes on the Mid-Atlantic Ridge

\begin{tabular}{rrrrc}
\hline Name & Latitude & Longitude & Strike & $\begin{array}{c}\text { Ref- } \\
\text { erence }\end{array}$ \\
\hline 8 & $35.29^{\circ} \mathrm{N}$ & $36.07^{\circ} \mathrm{W}$ & $86^{\circ}$ & $a$ \\
5 & $23.87^{\circ} \mathrm{N}$ & $45.96^{\circ} \mathrm{W}$ & $103^{\circ}$ & $a$ \\
4 & $10.77^{\circ} \mathrm{N}$ & $43.30^{\circ} \mathrm{W}$ & $90^{\circ}$ & $a$ \\
3 & $7.80^{\circ} \mathrm{N}$ & $37.35^{\circ} \mathrm{W}$ & $97^{\circ}$ & $a$ \\
2 & $7.45^{\circ} \mathrm{N}$ & $35.82^{\circ} \mathrm{W}$ & $100^{\circ}$ & $a$ \\
18 & $0.49^{\circ} \mathrm{S}$ & $19.95^{\circ} \mathrm{W}$ & 84 & $b$ \\
1 & $0.17^{\circ} \mathrm{S}$ & $18.70^{\circ} \mathrm{W}$ & $87^{\circ}$ & $a$ \\
\hline
\end{tabular}

a Sykes [1967].

${ }^{\circ}$ Sykes [1968a]. 


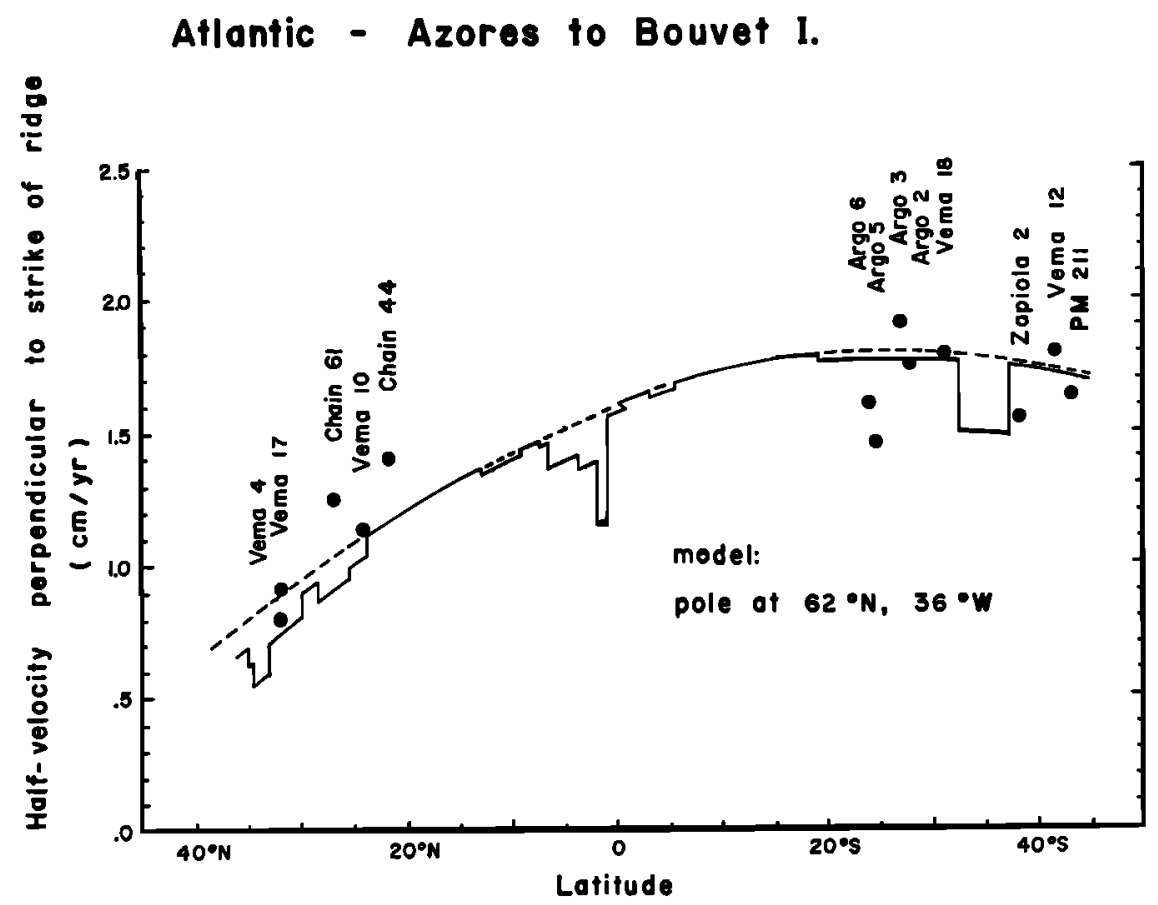

Fig. 9. Spreading rates determined from magnetic anomaly profiles are compared with the values caculated with the model. The solid line shows the predicted rate perpendicular to the strike of the ridge; the dashed line shows the rate parallel to the direction of spreading.

files (known distance from the crest of the ridge). Only that portion of Vine's time scale between 0 and 5 million years was used in determining the rates; as noted by Phillips [1967] either the spreading rates were about $25 \%$ faster previous to 5 million years ago or the time scale needs adjustment.

More magnetic profiles should be analyzed to critically test this hypothesis. The scatter in spreading rate values determined from adjacent ship tracks is likely due to numerous small fracture zones offsetting the anomaly pattern. An aeromagnetic survey of the scale of the U. S. Naval Oceanographic Office survey of the Reykjanes ridge [Heirtaler et al., 1966] would permit an unequivocal determination of spreading

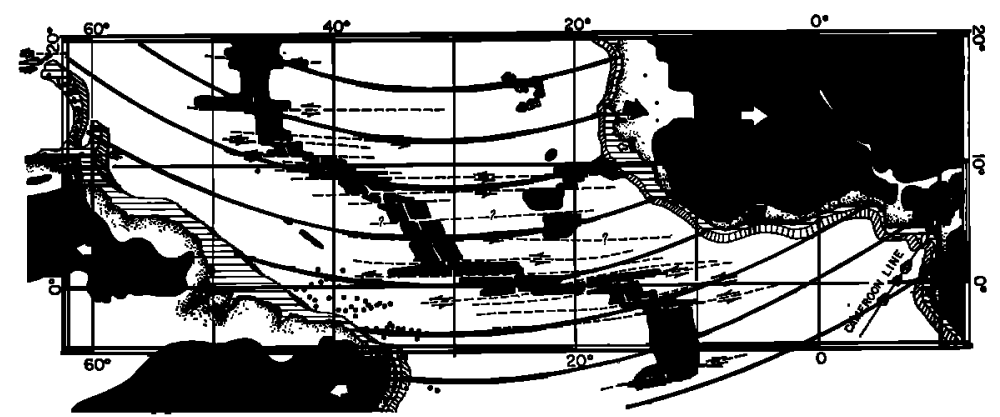

Fig. 10. The strike of the faults in the equatorial Atlantic are compared with circles concentric about a pole at $44.0^{\circ} \mathrm{N}, 30.6^{\circ} \mathrm{W}$, the pole about which South America must be rotated to make its coastline (500-fm isobath) coincide with the coastline of Africa [Bullard et al., 1965]. These circles indicate the average motion since drifting began. (Figure is adapted from Heezen and Tharp [1965].) 
rate and would afford a stringent test to this model. The area just south of $20^{\circ} \mathrm{N}$ has particular significance; a uniform change or discontinuous change in spreading rate here would show whether North America and South America move as a single block or as two blocks.

We may contrast this present motion of Africa and South America with the average motion of these two continents since they first split apart. This average motion is shown in Figure 10 and is quite different from the present motion indicated in Figure 7. The total length of the transform faults in this region suggests that about half of the motion of these two continents has been about the present pole. The earlier half of this total motion would have followed lines tending more northeast to southwest than the strike of the features observed in the center of the ocean.

\section{The Motion of the Pacific Block Relative to the North American Block}

Figure 11 shows the great fracture zones of the Pacific block. Menard's [1967] demonstration that these great fracture zones are not all great circles initiated the present investigation of crustal blocks. A set of circles concentric about a pole at $79^{\circ} \mathrm{N}, 111^{\circ} \mathrm{E}$ are superposed on this figure. Except for the Mendocino and Pio- neer fracture zones, the concentric circles are nearly coincident with the fracture zones. The Mendocino and Pioneer fracture zones depart from the circles farther west than do the other fracture zones; this departure is likely related to North America 'overriding' and interfering with the flow of the northernmost end of the rise at an earlier date. These old fracture zones indicate that the Pacific once moved away from North America toward trenches off New Guinea and the Phillipines. About 10 m.y. ago this pattern changed, and the Pacific now moves toward the Japan and Aleutian trenches.

We now consider the present boundary between the North American block and the Pacific block. This boundary is of the fault type from the Gulf of California to the Gulf of Alaska and is of the trench type along the Alaska Peninsula and Aleutian Islands. A small region, the Juan de Fuca block, is an anomalous region between these two large blocks. The boundaries of this block are shown in Figure 12. The trend of the Mendocino and Blanco fracture zones is not parallel to the trend of the San Andreas and Queen Charlotte faults, and we wish to justify exclusion of this region in our consideration of the motion of the Pacific block relative to the North American block. The belt of earthquakes between the Pacific and

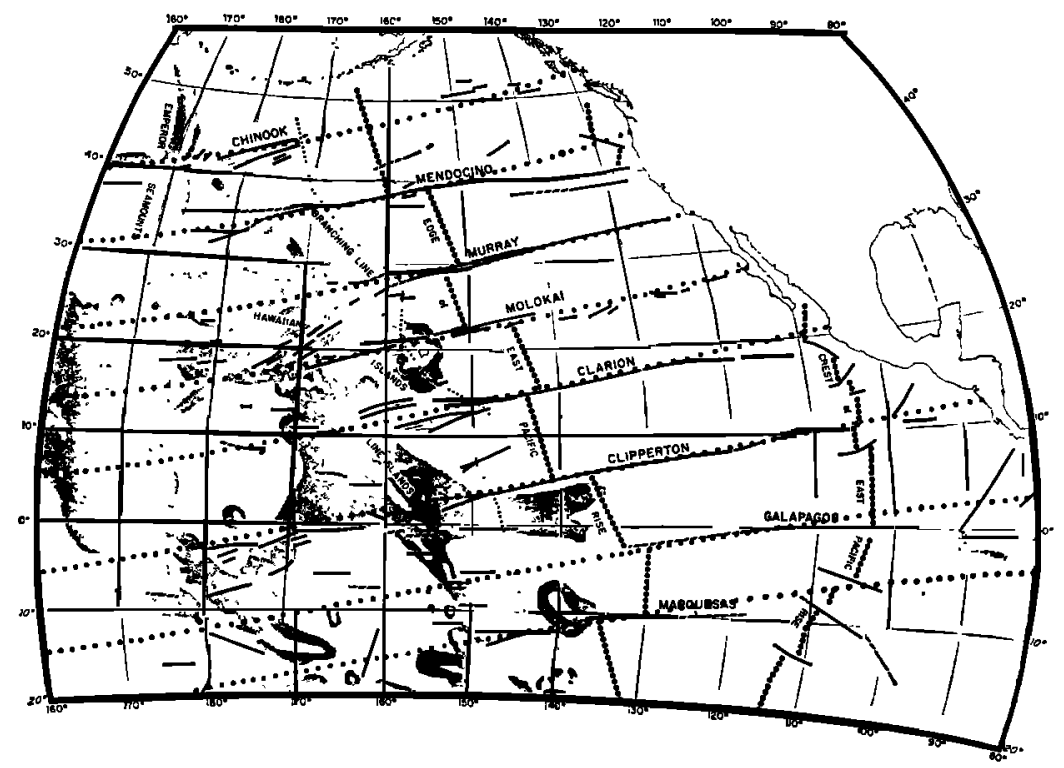

Fig. 11. Old fracture zones in the Pacific are compared with circles concentric about a pole at $79^{\circ} \mathrm{N}, 111^{\circ} \mathrm{E}$. (Figure is adapted from Menard [1967].) 


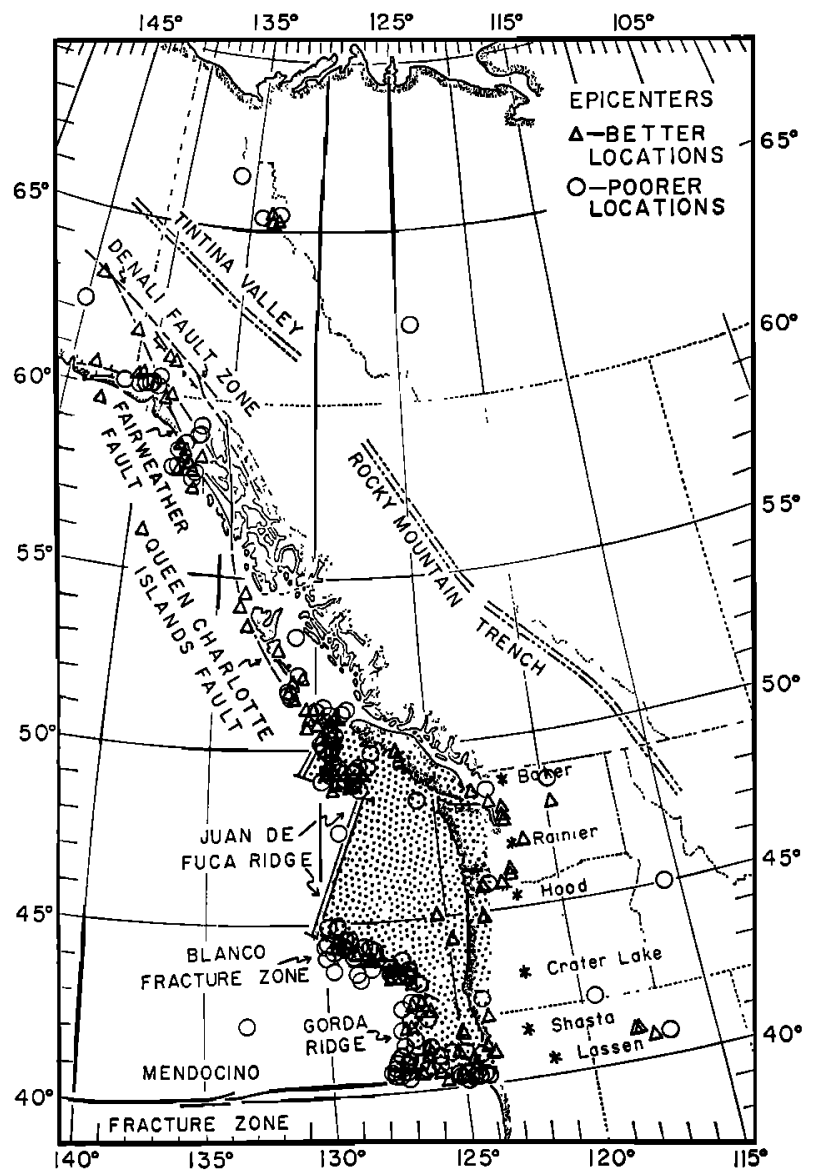

Fig. 12. The seismic belt along the west coast splits and follows the east and west boundaries of the Juan de Fuca block. Several large volcanic cones in the Cascades are identified. (Figure is adapted from Tobin and Sykes [1967].)

North America splits into two branches here (see Figure 12); the major branch follows the Mendocino and Blanco fracture zones, a less active branch follows what we suppose to be a compressive zone along the coast of Oregon and Washington. Figure 13 shows straight lines drawn on the magnetic diagram of Raff and Mason to indicate faults that offset the magnetic pattern. These faults are especially prominent in the color version of this figure appearing in Vine [1968]. As noted by Raff and Mason [1961], there are many faults at angles oblique to the main trends, and these faults suggest many small blocks moving independently of one another in this region. Detailed surveys of other rises will, perhaps, show that their magnetic patterns are equally broken up by oblique faults; in this event the argument advanced here on the anomalous nature of this small region will prove false. Note in particular the triangular shaped region $\mathrm{ABC}$ bounded by the coast line from $47^{\circ} \mathrm{N}$ to $42^{\circ} \mathrm{N}$, the Blanco fracture zone $\mathrm{AB}$, and the fault $\mathrm{BC}$, which begins at the intersection of the Blanco fracture zone and the Juan de Fuca ridge and heads at a $45^{\circ}$ strike toward Puget Sound. The magnetic pattern is offset on the fault $\mathrm{BC}$ by about $70 \mathrm{~km}$. This fault extended intercepts the Cascade Range near Mount Baker $\left(49^{\circ} \mathrm{N}\right)$, and the Blanco fracture zone extended intercepts the Cascade Range at Lassen Peak $\left(40^{\circ} \mathrm{N}\right)$. The volcanic Cascade Range lies between these two peaks. The Cascades and the sedimentary Coast Range were both formed at the close of the Plio- 


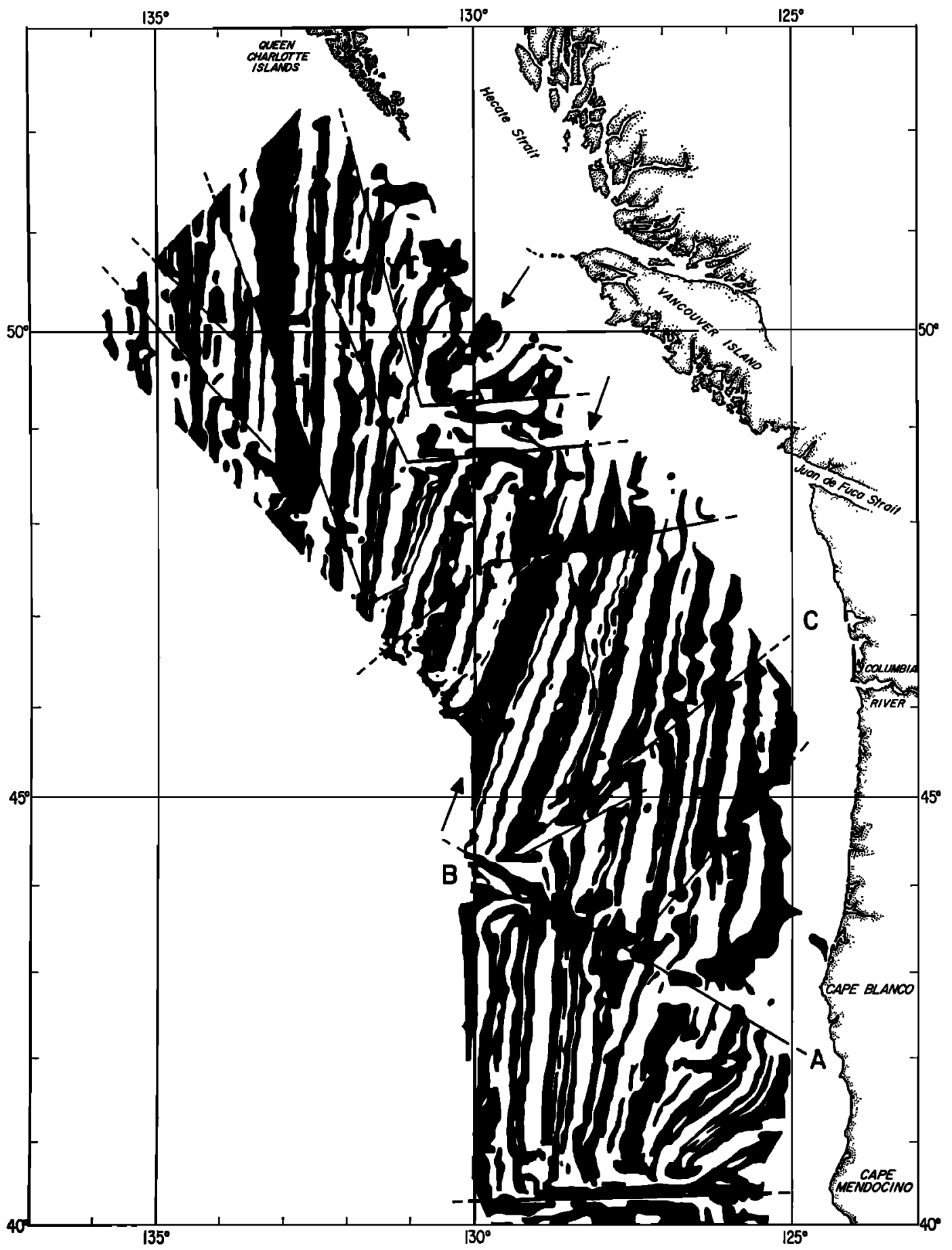

Fig. 13. Superposed on Raff and Mason's summary diagram of the magnetic anomalies in the Juan de Fuca region are arrows that indicate the axes of the three short ridge lengths in the area and straight lines that indicate faults offsetting the anomaly pattern [Vine, 1966]. 
cene and during the Pleistocene time. The Coast Ranges are probably the fill of an uplifted trench, and the Cascades are probably the volcanic counterpart of this now extinct system. The activity of this region is probably in its last stages; the fault BC is not seismically active at present. It appears as if this triangular block $A B C$ has moved eastward into North America with the crust thickening beneath the Coast Range or Cascades. The motion of this triangular block has possibly accommodated a variable spreading rate along the Juan de Fuca ridge; note the variable spreading rate along the Gorda ridge indicated by its fan-shaped magnetic anomaly pattern. On the basis of these arguments, we shall assume that the Juan de Fuca block moves independently of the Pacific and North America and shall ignore it in our discussion.

The faults used in this paper are listed in Table 3. The latitude and longitude of points at the northern and southern ends of a straight

TABLE 3. Strike of Major Transcurrent Faults on the West Coast of North America

\begin{tabular}{|c|c|c|c|c|c|c|}
\hline & Name & $\begin{array}{l}\text { Latitude and } \\
\text { Longitude } \\
\text { Northern } \\
\text { End }\end{array}$ & $\begin{array}{l}\text { Latitude and } \\
\text { Longitude } \\
\text { Southern } \\
\text { End }\end{array}$ & $\begin{array}{c}\text { Length } \\
\text { (Approx.), } \\
\text { km }\end{array}$ & $\begin{array}{c}\text { Strike } \\
\text { (Approx.), } \\
\text { deg }\end{array}$ & Reference \\
\hline \multicolumn{7}{|c|}{ Fairweather-Queen Charlotte } \\
\hline 1. & Russell Fiord & $\begin{array}{r}60.043^{\circ} \mathrm{N} \\
139.512^{\circ} \mathrm{W}\end{array}$ & $\begin{array}{r}59.848^{\circ} \mathrm{N} \\
139.274^{\circ} \mathrm{W}\end{array}$ & 26 & 149 & $a$ \\
\hline 2. & $\begin{array}{l}\text { SE of Nunatak } \\
\text { Fiord }\end{array}$ & $\begin{array}{r}59.814^{\circ} \mathrm{N} \\
139.000^{\circ} \mathrm{W}\end{array}$ & $\begin{array}{r}59.390^{\circ} \mathrm{N} \\
138.336^{\circ} \mathrm{W}\end{array}$ & 60 & 142 & $b$ \\
\hline 3. & $\begin{array}{l}\text { Alsek River and } \\
\text { Glacier }\end{array}$ & $\begin{array}{r}59.390^{\circ} \mathrm{N} \\
138.336^{\circ} \mathrm{W}\end{array}$ & $\begin{array}{r}59.046^{\circ} \mathrm{N} \\
138.000^{\circ} \mathrm{W}\end{array}$ & 45 & 153 & $b$ \\
\hline 4. & $\begin{array}{l}\text { Fairweather Trench } \\
\text { Lituya Bay }\end{array}$ & $\begin{array}{r}59.031^{\circ} \mathrm{N} \\
138.000^{\circ} \mathrm{W}\end{array}$ & $\begin{array}{r}58.583^{\circ} \mathrm{N} \\
137.361^{\circ} \mathrm{W}\end{array}$ & 61 & 143 & $b, c$ \\
\hline 5. & North Dome & $\begin{array}{c}58.583^{\circ} \mathrm{N} \\
137.361^{\circ} \mathrm{W}\end{array}$ & $\begin{array}{r}58.553^{\circ} \mathrm{N} \\
137.309^{\circ} \mathrm{W}\end{array}$ & 5 & 139 & $c$ \\
\hline 6. & La Perouse Glacier & $\begin{array}{r}58.553^{\circ} \mathrm{N} \\
137.309^{\circ} \mathrm{W}\end{array}$ & $\begin{array}{r}58.504^{\circ} \mathrm{N} \\
137.211^{\circ} \mathrm{W}\end{array}$ & 8 & 134 & $a$ \\
\hline 7. & South Dome & $\begin{array}{r}58.504^{\circ} \mathrm{N} \\
137.211^{\circ} \mathrm{W}\end{array}$ & $\begin{array}{r}58.483^{\circ} \mathrm{N} \\
137.176^{\circ} \mathrm{W}\end{array}$ & 3 & 138 & $c$ \\
\hline 8. & Kaknau Creek & $\begin{array}{r}58.442^{\circ} \mathrm{N} \\
137.124^{\circ} \mathrm{W}\end{array}$ & $\begin{array}{r}58.393^{\circ} \mathrm{N} \\
137.073^{\circ} \mathrm{W}\end{array}$ & 6 & 151 & $c$ \\
\hline 9. & $\begin{array}{l}\text { Crillion Lake to } \\
\text { Palma Bay }\end{array}$ & $\begin{array}{r}58.583^{\circ} \mathrm{N} \\
137.361^{\circ} \mathrm{W}\end{array}$ & $\begin{array}{r}58.393^{\circ} \mathrm{N} \\
137.073^{\circ} \mathrm{W}\end{array}$ & 29 & 142 & $5,6,7,8$ \\
\hline 10. & Chichagof Island & $\begin{array}{c}58.00^{\circ} \mathrm{N} \\
136.65^{\circ} \mathrm{W}\end{array}$ & $\begin{array}{r}57.48^{\circ} \mathrm{N} \\
136.00^{\circ} \mathrm{W}\end{array}$ & 70 & 146 & $d$ \\
\hline 11. & Baranof Island & $\begin{array}{r}57.00^{\circ} \mathrm{N} \\
135.54^{\circ} \mathrm{W}\end{array}$ & $\begin{array}{r}56.00^{\circ} \mathrm{N} \\
134.64^{\circ} \mathrm{W}\end{array}$ & 125 & 154 & $d$ \\
\hline 12. & $\begin{array}{l}\text { Queen Charlotte } \\
\text { Islands (N) }\end{array}$ & $\begin{array}{r}54.00^{\circ} \mathrm{N} \\
133.43^{\circ} \mathrm{W}\end{array}$ & $\begin{array}{r}52.93^{\circ} \mathrm{N} \\
132.42^{\circ} \mathrm{W}\end{array}$ & 130 & 151 & $d, e$ \\
\hline 13. & $\begin{array}{l}\text { Queen Charlotte } \\
\text { Islands (S) }\end{array}$ & $\begin{array}{r}52.93^{\circ} \mathrm{N} \\
132.42^{\circ} \mathrm{W}\end{array}$ & $\begin{array}{r}52.00^{\circ} \mathrm{N} \\
131.15^{\circ} \mathrm{W}\end{array}$ & 130 & 140 & $d, e$ \\
\hline \multicolumn{7}{|c|}{ Northern California } \\
\hline 1. & Pt. Arena & $\begin{array}{r}39.00^{\circ} \mathrm{N} \\
123.69^{\circ} \mathrm{W}\end{array}$ & $\begin{array}{r}38.48^{\circ} \mathrm{N} \\
123.19^{\circ} \mathrm{W}\end{array}$ & 72 & 143 & $f$ \\
\hline 2. & Tomales Bay & $\begin{array}{r}38.24^{\circ} \mathrm{N} \\
122.98^{\circ} \mathrm{W}\end{array}$ & $\begin{array}{r}37.91^{\circ} \mathrm{N} \\
122.68^{\circ} \mathrm{W}\end{array}$ & 45 & 144 & $f$ \\
\hline 3. & San Andreas Lake & $\begin{array}{r}37.70^{\circ} \mathrm{N} \\
122.50^{\circ} \mathrm{W}\end{array}$ & $\begin{array}{r}37.55^{\circ} \mathrm{N} \\
122.37^{\circ} \mathrm{W}\end{array}$ & 20 & 145 & $f$ \\
\hline 4. & & $\begin{array}{r}37.48^{\circ} \mathrm{N} \\
122.31^{\circ} \mathrm{W}\end{array}$ & $\begin{array}{r}37.29^{\circ} \mathrm{N} \\
122.11^{\circ} \mathrm{W}\end{array}$ & 27 & 140 & $f$ \\
\hline 5. & San Juan Batista & $\begin{array}{r}37.12^{\circ} \mathrm{N} \\
121.91^{\circ} \mathrm{W}\end{array}$ & $\begin{array}{r}36.91^{\circ} \mathrm{N} \\
121.59^{\circ} \mathrm{W}\end{array}$ & 37 & 130 & $f$ \\
\hline 6. & San Juan Batista & $\begin{array}{r}36.47^{\circ} \mathrm{N} \\
121.07^{\circ} \mathrm{W}\end{array}$ & $\begin{array}{r}36.29^{\circ} \mathrm{N} \\
120.89^{\circ} \mathrm{W}\end{array}$ & 26 & 141 & $f$ \\
\hline
\end{tabular}


TABLE 3 (continued)

\begin{tabular}{|c|c|c|c|c|c|c|}
\hline & Ṅame & $\begin{array}{l}\text { Latitude and } \\
\text { Longitude } \\
\text { Northern } \\
\text { End }\end{array}$ & $\begin{array}{l}\text { Latitude and } \\
\text { Longitude } \\
\text { Southern } \\
\text { End }\end{array}$ & $\begin{array}{l}\text { Length } \\
\text { (Approx.), } \\
\text { km }\end{array}$ & $\begin{array}{c}\text { Strike } \\
\text { (Approx.), } \\
\text { deg }\end{array}$ & Reference \\
\hline 7. & & $\begin{array}{r}36.29^{\circ} \mathrm{N} \\
120.89^{\circ} \mathrm{W}\end{array}$ & $\begin{array}{r}36.00^{\circ} \mathrm{N} \\
120.57^{\circ} \mathrm{W}\end{array}$ & 43 & 139 & $f$ \\
\hline 8. & & $\begin{array}{c}35.71^{\circ} \mathrm{N} \\
120.26^{\circ} \mathrm{W}\end{array}$ & $\begin{array}{r}35.36^{\circ} \mathrm{N} \\
119.91^{\circ} \mathrm{W}\end{array}$ & 50 & 141 & $f$ \\
\hline 9. & & $\begin{array}{r}35.36^{\circ} \mathrm{N} \\
119.91^{\circ} \mathrm{W}\end{array}$ & $\begin{array}{r}35.07^{\circ} \mathrm{N} \\
119.58^{\circ} \mathrm{W}\end{array}$ & 44 & 137 & $f$ \\
\hline \multicolumn{7}{|c|}{ Southern California } \\
\hline 1. & Elsinor & $\begin{array}{c}33.82^{\circ} \mathrm{N} \\
117.57^{\circ} \mathrm{W}\end{array}$ & $\begin{array}{c}33.63^{\circ} \mathrm{N} \\
117.32^{\circ} \mathrm{W}\end{array}$ & 31 & 133 & $f$ \\
\hline 2. & Elsinor & $\begin{array}{r}33.27^{\circ} \mathrm{N} \\
116.87^{\circ} \mathrm{N}\end{array}$ & $\begin{array}{r}33.00^{\circ} \mathrm{N} \\
116.41^{\circ} \mathrm{W}\end{array}$ & 52 & 125 & $f$ \\
\hline 3. & San Jacino & $\begin{array}{r}33.55^{\circ} \mathrm{N} \\
116.64^{\circ} \mathrm{W}\end{array}$ & $\begin{array}{r}33.31^{\circ} \mathrm{N} \\
116.32^{\circ} \mathrm{W}\end{array}$ & 40 & 131 & $f$ \\
\hline 4. & San Jacino & $\begin{array}{r}32.28^{\circ} \mathrm{N} \\
115.14^{\circ} \mathrm{W}\end{array}$ & $\begin{array}{r}32.09^{\circ} \mathrm{N} \\
114.93^{\circ} \mathrm{W}\end{array}$ & 29 & 136 & $g$ \\
\hline 5. & San Andreas & $\begin{array}{r}33.74^{\circ} \mathrm{N} \\
116.22^{\circ} \mathrm{W}\end{array}$ & $\begin{array}{r}33.57^{\circ} \mathrm{N} \\
116.00^{\circ} \mathrm{W}\end{array}$ & 28 & 132 & $f$ \\
\hline 6. & Imperial & $\begin{array}{c}33.00^{\circ} \mathrm{N} \\
115.62^{\circ} \mathrm{W}\end{array}$ & $\begin{array}{r}32.69^{\circ} \mathrm{N} \\
115.33^{\circ} \mathrm{W}\end{array}$ & 44 & 142 & $f$ \\
\hline 7. & Imperial & $\begin{array}{r}33.00^{\circ} \mathrm{N} \\
115.62^{\circ} \mathrm{W}\end{array}$ & $\begin{array}{r}32.50^{\circ} \mathrm{N} \\
115.17^{\circ} \mathrm{W}\end{array}$ & 70 & 143 & $g$ \\
\hline \multicolumn{7}{|c|}{ Gulf of California } \\
\hline 1. & Sal si Puedes & $\begin{array}{r}29.339^{\circ} \mathrm{N} \\
113.617^{\circ} \mathrm{W}\end{array}$ & $\begin{array}{c}28.444^{\circ} \mathrm{N} \\
112.495^{\circ} \mathrm{W}\end{array}$ & 147 & 132 & $h$ \\
\hline 2. & & $\begin{array}{r}26.716^{\circ} \mathrm{N} \\
111.151^{\circ} \mathrm{W}\end{array}$ & $\begin{array}{r}26.225^{\circ} \mathrm{N} \\
110.420^{\circ} \mathrm{W}\end{array}$ & 90 & 127 & $h$ \\
\hline 3. & & $\begin{array}{r}25.150^{\circ} \mathrm{N} \\
109.764^{\circ} \mathrm{W}\end{array}$ & $\begin{array}{r}24.670^{\circ} \mathrm{N} \\
109.000^{\circ} \mathrm{W}\end{array}$ & 94 & 125 & $h$ \\
\hline 4. & & $\begin{array}{r}24.116^{\circ} \mathrm{N} \\
109.000^{\circ} \mathrm{W}\end{array}$ & $\begin{array}{r}23.473^{\circ} \mathrm{N} \\
108.000^{\circ} \mathrm{W}\end{array}$ & 124 & 125 & $h$ \\
\hline
\end{tabular}

- Davis and Sanders [1960], Figure 1.

- Davis and Sanders [1960], Figure 2, and Tocher [1960], Table 1.

- Tocher [1960], Table 1 and Plate 1.

d St. Amand [1957], Figure 7.

- 200-fm line on U.S.G.S. Geologic Map of North America, 1965.

$\checkmark$ Geologic Map of California, Plate 1 of California Div. Mines and Geology Bulletin 190, 1966.

- Biehler et al. [1964], Chart 1.

n Rusnak et al. [1964], Plate 3.

fault segment are listed here along with the length and strike of the segment between the two end points. A great circle was constructed which passes midway between the points at right angles to the segment joining them. As shown in Figure 14e, these great circles perpendicular to the fault segments have a common intersection near $53^{\circ} \mathrm{N}, 53^{\circ} \mathrm{W}$; we shall return to this summary figure after discussing the faults in each region.
The fault segments in the Fairweather-Queen Charlotte region generally follow the line drawn by St. Amand [1957]. On July 10, 1958, a large earthquake occurred on the Fairweather fault, and the first nine faults listed in the table are from papers based on field work in this area immediately after this earthquake. The Fairweather fault has a total length of $200 \mathrm{~km}$, of which $90 \%$ is covered with ice, water, or unconsolidated sediments. The only observed fault 
traces were observed at the northern tip of fault 2, at the southern tip of fault 4, and along faults 5,7 , and 8 . The strikes of the longer faults (no. 2, $60 \mathrm{~km}$; no. $3,45 \mathrm{~km}$; no. $4,61 \mathrm{~km}$ ) are thus inferred from the topography of the glacier filled troughs. The three short observed fault traces (no. 5, $5 \mathrm{~km}$; no. 7, $3 \mathrm{~km}$; no. $8,6 \mathrm{~km}$ ) and the segment through La Perouse glacier that connects the end points of 5 and 7 (no. 6, $8 \mathrm{~km}$ ) were used in constructing Figure $14 a$. There is a $17^{\circ}$ difference in the strikes of parts of these four segments. However, even the very straight San Andreas fault in northern California has $10^{\circ}$ variations rather continuously along short $(5 \mathrm{~km})$ segments of its total length. (See for example figures in Oakeshott [1966] and Dibblee [1966]). To reduce this scatter, an average fault was constructed from the beginning of fault 5 to the end point of fault 8 . This average fault (no. 9, $26 \mathrm{~km}$ ) was used in Figure $14 e$ in place of faults $5,6,7$, and 8.

In northern California, nine segments of the San Andreas fault are tabulated; lines constructed perpendicular to these segments are shown in Figure 14b. Only one fault, no. 5 near San Juan Batista, has a strike notably different from the others. At this location, the San Andreas fault splits into two parallel branches, the northwestern branch being the San Andreas fault and the northeastern branch being the active Haywards fault and Calaveras fault. In light of the special nature of this junction, fault 5 has been omitted from the summary diagram in Figure $14 e$.

In southern California, the fault segments chosen are presumably the major faults of the region. This choice was based on articles by Biehler et al. [1964] and Allen et al. [1965]. One segment, the Elsinor no. 2, has a strike notably different from the others, and it was omitted from Figure 14e. The two entries for the Imperial fault are not independent: one entry was taken from a source that extended only to the international border; the second entry includes that half of the Imperial fault which is in Mexico. The tensional or compressional nature of individual features in southern California is qualitatively explained by the difference between the strike of a feature and the average strike of the region. The Salton trough (general strike $150^{\circ}$ ) is a depressed region; the Salton Sea is 75 meters below sea level. The ob- served surface faults in the trough do not run the length of the trough but are arranged en echelon with each fault having a strike of about $140^{\circ}$. In contrast, the Transverse Range (general strike $110^{\circ}$ ) reaches an altitude of 3 $\mathrm{km}$. A major transcurrent fault, the Garlock fault, runs east-west just north of the Transverse Range. The motion on this fault is such as to move a wedge-shaped block eastward to relieve the north-south compressive stresses occurring at this bottleneck. A similar pattern occurs in Arabia. The strikes of the Gulf of Aqaba and the Dead Sea are inclined to one side, and the strike of the short mountain range in Lebanon is inclined to the other side, of a smooth small circle representing the motion of Arabia relative to the African-Mediterranean block.

The four faults in the Gulf of California were taken from the fault map of Rusnak et al. [1964]. The line perpendicular to the longest and best defined of these faults, the Sal si Puedes fault, passes through the center of the circle of intersection as shown in Figure 14d. With hindsight, a different choice of faults in the southern part of the Gulf could be made that would allow all the perpendiculars to pass near the center of the circle. The apparently systematic shift in the lines 1, 2,3, and 4 should not be considered significant.

The lines in Figures $14 a$ and $14 b$, with the exceptions noted in the text above, are all drawn in Figure 14e. All of these lines pass through the circle centered at $53^{\circ} \mathrm{N}, 53^{\circ} \mathrm{W}$. The size and location of the circle, $53^{\circ} \mathrm{N}\left( \pm 6^{\circ}\right)$, $53^{\circ} \mathrm{W}\left( \pm 10^{\circ}\right)$, were chosen to fit the intersections in Figures $14 e$ and 14f; the same circle has been drawn in all six figures. The scatter in the strikes of neighboring faults is larger on this boundary than was the scatter in the Atlantic Ocean. We cannot determine the distance between a region and the pole from the intersection of the great circles constructed for Alaska alone or California alone. This might be expected if the surface expression of a fault in continental regions is more irregular than in oceanic regions. Alaska and California are sufficiently far apart to compensate for the scatter in strikes in a single region. The great circles of the two regions intersect at large angles and precisely locate the best pole. We may suppose that the accuracy in determining the center of the 


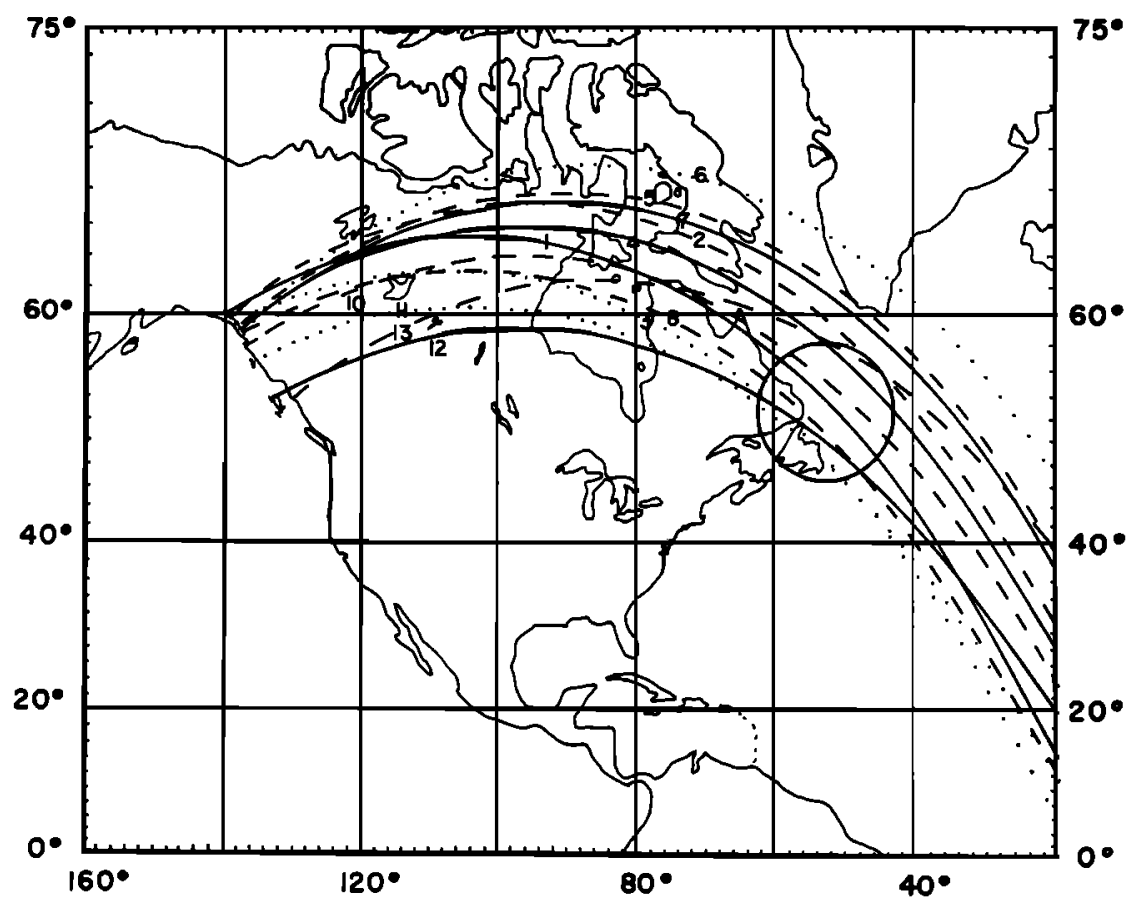

Fig. 14a

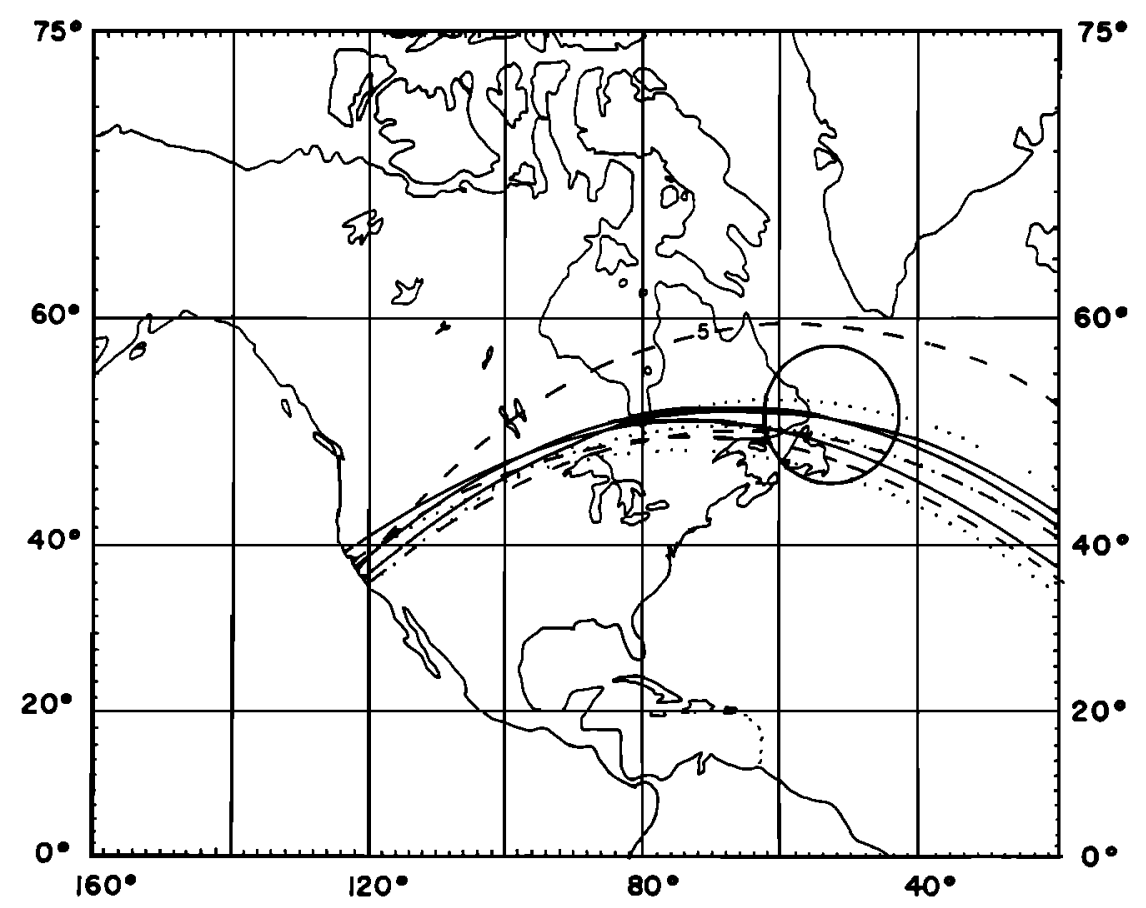

Fig. $14 b$ 


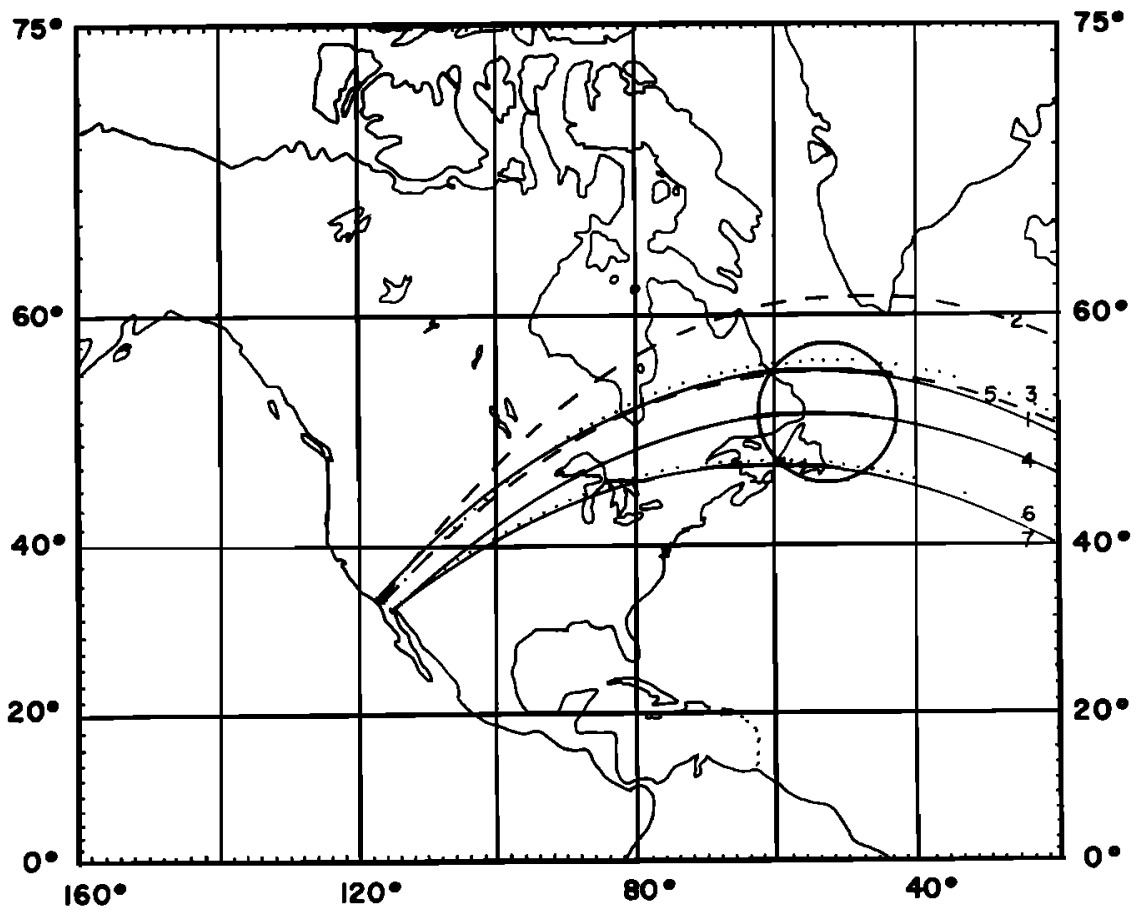

Fig. $14 c$

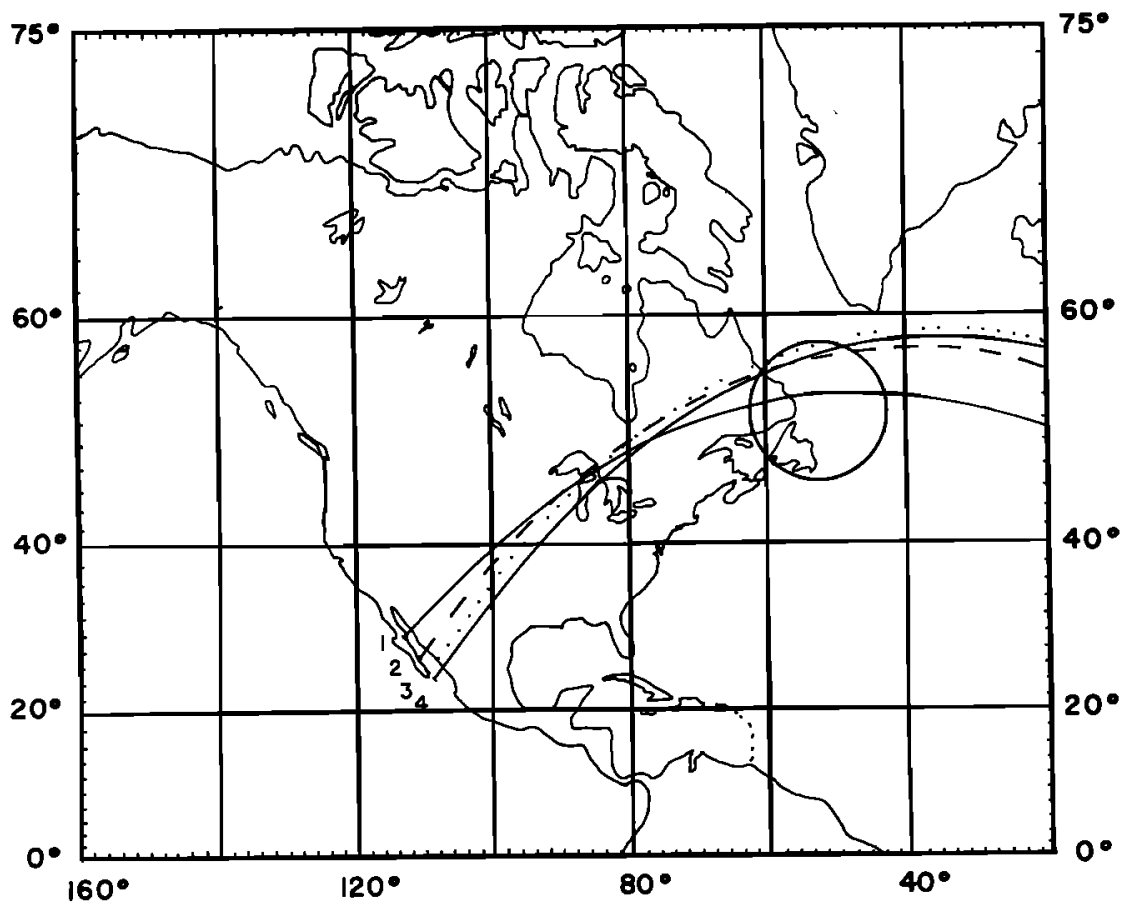

Fig. 14d 


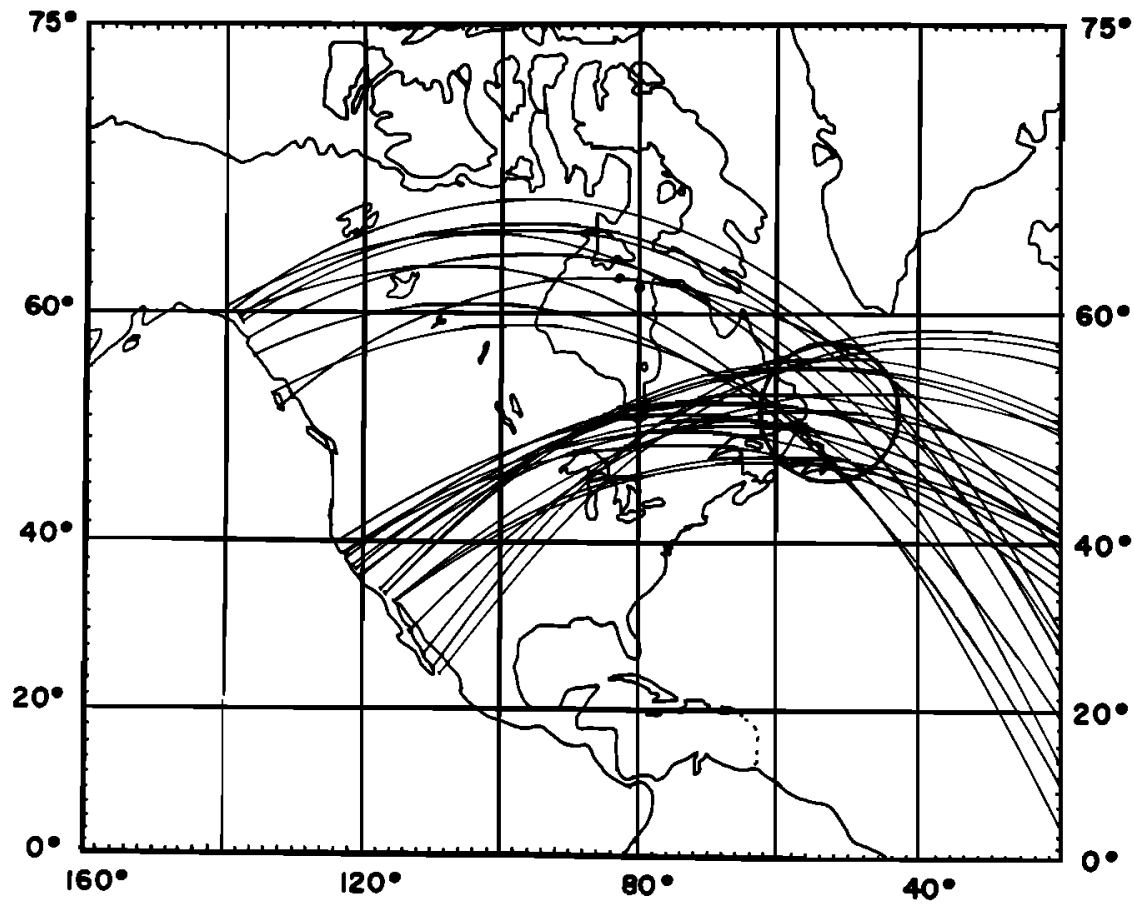

Fig. 14e

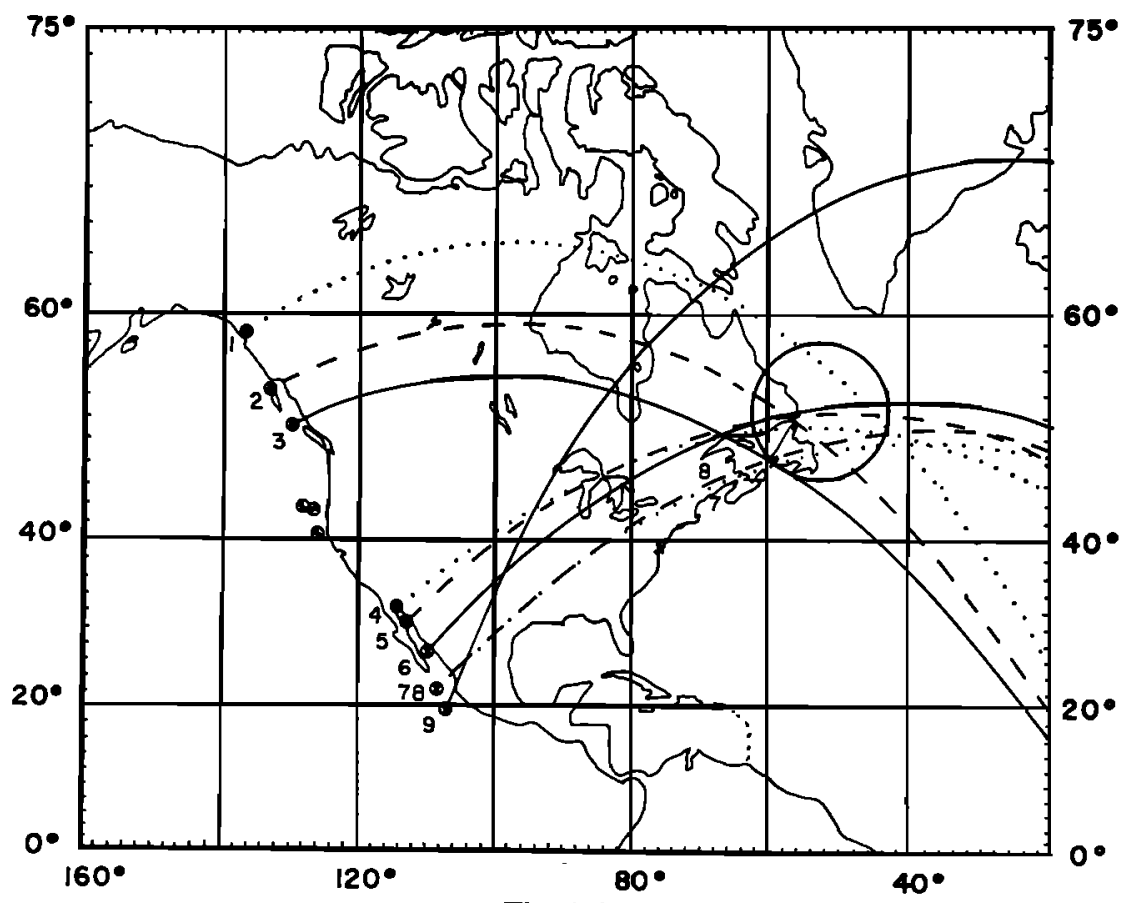

Fig. $14 f$

Fig. 14. Parts (a) through $(d)$ show great circles constructed perpendicular to the strikes of fault segments observed in the Fairweather-Queen Charlotte, northern California, southern California, and Gulf of California regions. Part $(e)$ is a composite of the four separate regions with the exceptions noted in the text. Part $(f)$ shows great circles constructed perpendicular to strikes determined from earthquake mechanism solutions. The circle of intersection drawn has the coordinates $53^{\circ} \mathrm{N}\left( \pm 6^{\circ}\right), 53^{\circ} \mathrm{W},\left( \pm 10^{\circ}\right)$. 
circle of intersection is half the radius of the circle drawn in the figure; the pole is then located at $53^{\circ} \mathrm{N}\left( \pm 3^{\circ}\right), 53^{\circ} \mathrm{W}\left( \pm 5^{\circ}\right)$.

The strikes of fault planes of nine earthquake mechanism solutions are listed in Table 4 . Lines drawn perpendicular to these strikes are shown in Figure 14f. The epicenters of three additional earthquakes for which solutions have been determined [Tobin and Sykes, 1967] are also shown in this figure. These three earthquakes occurred on the boundary between the Pacific and Juan de Fuca blocks; therefore their perpendiculars were not constructed. Earthquake 9 on the Rivera fracture zone occurs on a tongue of the North American block that sticks out into the Pacific block and partially surrounds part of the Middle America trench. It is not surprising that the direction of this earthquake departs from the strike of the other earthquakes. Earthquakes 7 and 8 , which are only $200 \mathrm{~km}$ away from the Rivera earthquake, however, have strikes parallel to the earthquakes farther north in the Gulf.

We may assign a rate to the motion of the Pacific block relative to North America if we assume that the motion along the San Andreas fault is $6 \pm 1 \mathrm{~cm} / \mathrm{yr}$ [Hamilton and Meyers, 1966]. Converting this value into half-velocity and taking into account that the San Andreas fault is $49^{\circ}$ form the pole at $53^{\circ} \mathrm{N}, 53^{\circ} \mathrm{W}$, we find $V_{\max }=4.0 \pm 0.6 \mathrm{~cm} / \mathrm{yr}$. This rate is based on recent movements of the San Andreas fault. In the Atlantic, the magnetic pattern produced

TABLE 4. Strikes Determined from Transcurrent Type Earthquake Mechaniam Solutions

\begin{tabular}{lcccc}
\hline & $\begin{array}{c}\text { Lati- } \\
\text { tude, } \\
\text { Name }\end{array}$ & $\begin{array}{c}\text { Longi- } \\
\text { tude, } \\
{ }^{\circ} \mathrm{W}\end{array}$ & $\begin{array}{c}\text { Strike, } \\
\text { deg }\end{array}$ & $\begin{array}{c}\text { Refer- } \\
\text { ence }\end{array}$ \\
\hline & & & & \\
\hline 1. Fairweather & 58.33 & 136.92 & 145 & $a$ \\
2. Queen Charlotte & 54.10 & 132.58 & 151 & $b$ \\
3. Queen Charlotte & 50.81 & 130.15 & 155 & $c$ \\
4. Gulf of California & 31.72 & 114.42 & 138 & $d$ \\
5. Gulf of California & 29.68 & 113.74 & 135 & $d$ \\
6. Gulf of California & 26.26 & 110.22 & 132 & $d$ \\
7. Gulf of California & 21.36 & 108.65 & 134 & $d$ \\
8. Gulf of California & 21.26 & 108.75 & 133 & $d$ \\
9. Rivera Fault Zone & 18.87 & 107.18 & 112 & $e$ \\
\hline
\end{tabular}

- Stauder [1960].

- Hodgson and Milne [1951].

- Tobin and Sykes [1967].

d Sylkes [1968a]

- Sykes [1967]. during the past 5 million years was used to determine the spreading rate; hence, that rate is an average rate for 5 million years. The rate for the Pacific block relative to North America might be based on the same standard if magnetic profiles oriented parallel to the transform faults in the Gulf of California were analyzed.

\section{The Motion of the Antarctic Block Relative to the Pacific Block}

A study of the motion of the Antarctic block relative to the Pacific block was made, and a pole at $71 \pm 2^{\circ} \mathrm{S}, 118 \pm 6^{\circ} \mathrm{E}$ with an equatorial half-velocity of $5.7 \pm 0.3 \mathrm{~cm} / \mathrm{yr}$ was found. The data on which this study is based are given in Pitman et al. [1968] and also in Heirtzler [1968]. Le Pichon [1968] has also investigated this region and has found a pole position practically identical to that listed above. A listing of the strikes of faults and spreading rates is given in Le Pichon's paper and will not be repeated here.

Six large fracture zones offsetting the PacificAntarctic ridge have recently been delineated by the authors listed above. Great circles were constructed perpendicular to the strike of these fracture zones, and, as shown in Figure 15, these great circles all pass within $2^{\circ}$ of a pole at $71^{\circ} \mathrm{S}, 118^{\circ} \mathrm{E}$. This pole position was chosen using both the constructed great circles and the spreading rate data, which will be discussed next. The great circles intersect at grazing angles and give good control only in the latitude of the pole; the spreading rates provide the control in the other direction.

Magnetic profiles of twelve crossings of this ridge have been presented by Heirtaler [1968] and Pitman et al. [1968]. Ten of these profiles were analyzed in the following manner to obtain the spreading rates shown in Figure 16. The profile Eltanin $19 \mathrm{~N}$ was taken to be the standard, and a spreading rate of $4.40 \mathrm{~cm} / \mathrm{yr}$ was assigned to it. This rate is in agreement with the Vine [1966] time scale used here in the analysis of the Atlantic Ocean spreading rates; if a different time scale is to be used, all rates here will be scaled up or down by the same factor. The central portion of this profile, corresponding to the spreading within about the last $8 \mathrm{~m} . \mathrm{y}$., was examined and the distance from the center of the profile to each distinctive peak or valley of the profile was noted. Each profile was so 


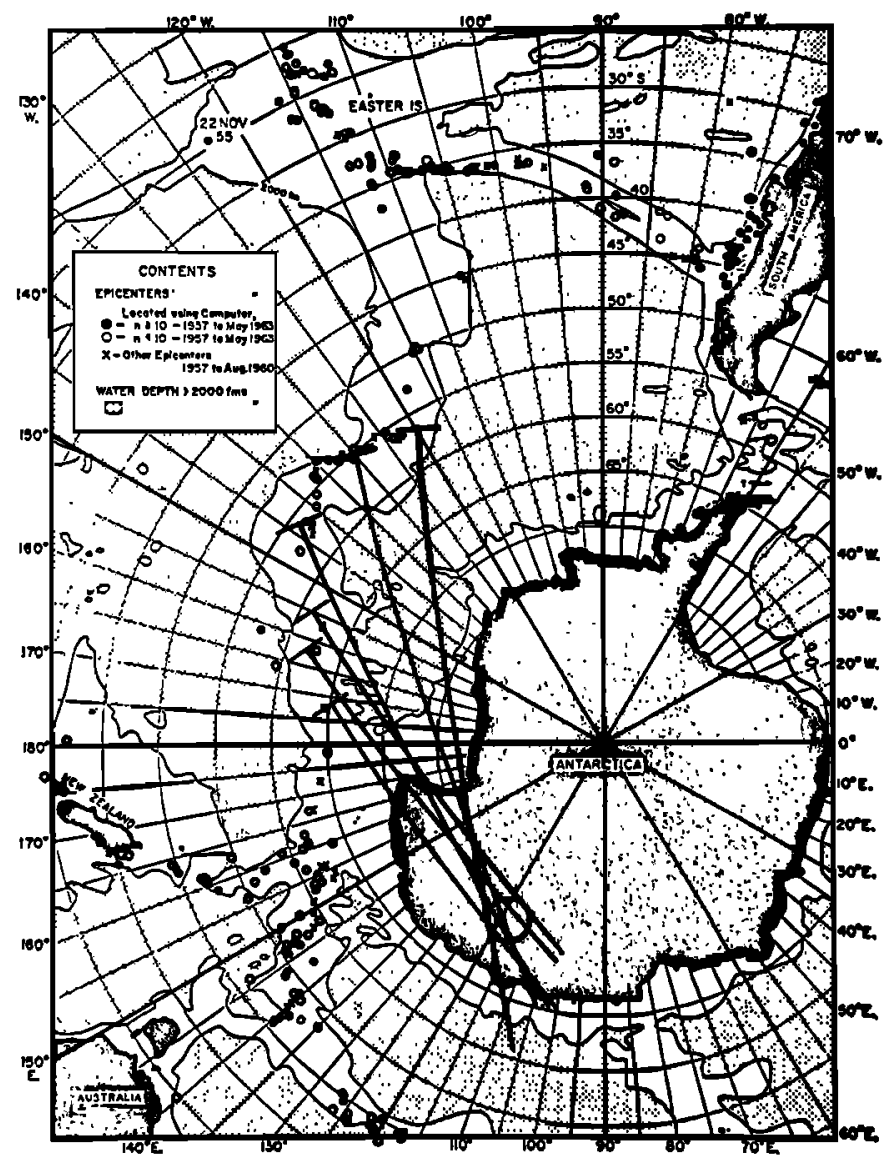

Fig. 15. Great circles constructed perpendicular to the strike of fracture zones offsetting the Pacific-Antarctic ridge are plotted on Sykes's [1963] seismic map of this region. The great circles all pass within $2^{\circ}$ of the pole at $71^{\circ} \mathrm{S}, 118^{\circ} \mathrm{E}$.

examined and the ratio of its spreading rate relative to the standard was found. On some profiles, an apparently perfect matching of each peak of the profile to the corresponding peak of the standard was made, and the error in determining the rate is small. On other profiles the peaks within the interval corresponding to less than $8 \mathrm{~m} . \mathrm{y}$. could not be matched with certainty, or a large number of offsets broke the pattern into many short matchable segments, and the error in determing the rate is large. The open circles and error flags in Figure 16 show the rates and estimated errors so found. These are rates perpendicular to the strike of the ridge, as the profiles examined had been projected perpendicular to the ridge. The crosses in the figure show $V_{\theta}$, the rate projected parallel to the direction of spreading as described in Figure 5. The dashed line computed for $V_{\max }=5.7$ $\mathrm{cm} / \mathrm{yr}$ should pass through all of the crosses if there were no errors in the analysis (or in the hypothesis of rigid blocks).

No attempt was made to construct a diagram predicting the spreading rate perpendicular to the strike of the ridge as was done for the Atlantic. The crossings of the ridge are spaced about 1 every $500 \mathrm{~km}$, and the strike of the ridge is simply not known. It is interesting to note that the three profiles easiest to interpret, EL19N, SI8, and SI6, had ship's tracks inclined $7^{\circ}$ or less from the direction of spreading inferred from a pole position at $71^{\circ} \mathrm{S}, 118^{\circ} \mathrm{E}$. In general, the greater the angle between the ship track and the direction of spreading, the more 


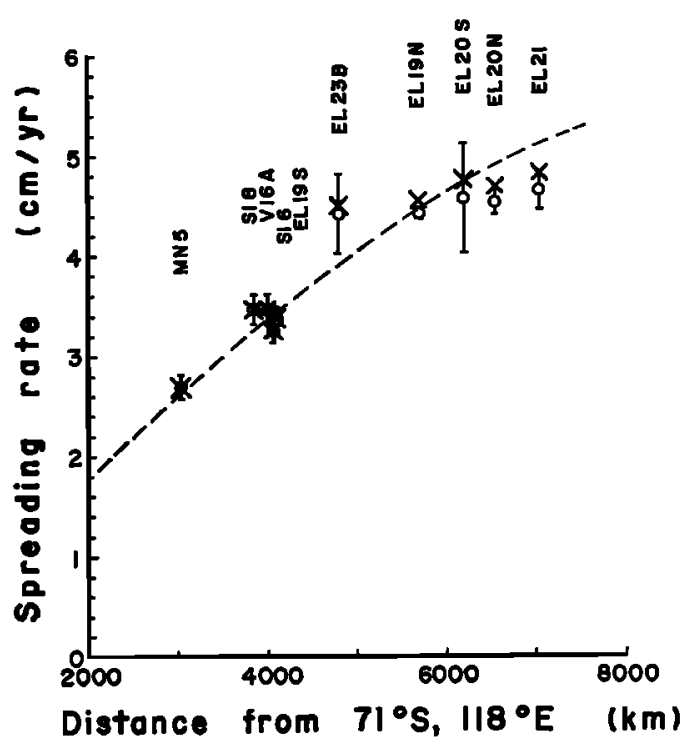

Fig. 16. Spreading rates on the Pacific-Antarctic ridge are compared with a model with $V_{\max }=5.7 \mathrm{~cm} / \mathrm{yr}$ about a pole at $71^{\circ} \mathrm{S}, 118^{\circ} \mathrm{E}$. The circles are the spreading rates measured perpendicular to the strike of the ridge; the crosses are these rates projected parallel to the direction of spreading.

often offsets in the magnetic pattern were observed. It seems likely, therefore, that the $\mathrm{Pa}$ cific-Antarctic ridge is offset by many small fracture zones (the offsets noted here ranged from $10 \mathrm{~km}$ to $40 \mathrm{~km}$ ); this ridge has, perhaps, a pattern similar to that observed in the equatorial Atlantic Ocean. If this is so, the 'local' strike of the ridge, the strike that must be used in projecting a profile, might differ significantly from the 'general' strike determined from widely spaced crossings of the ridge. The crossings SI3 and SI5 presented in the references above are not shown in Figure 16 because of the uncertainty in projection. Rates of $2.50 \pm$ $0.50 \mathrm{~cm} / \mathrm{yr}$ and $2.68 \pm 0.10 \mathrm{~cm} / \mathrm{yr}$ were deter- mined for SI3 and SI5, respectively, along the projected profiles presented in Pitman et al. [1968]. If the strike of the ridge is perpendicular to the fracture zones here, i.e., the ridge strike is $45^{\circ}$, the velocities parallel to the spreading direction are $2.0 \mathrm{~cm} / \mathrm{yr}$ and $2.5 \mathrm{~cm} / \mathrm{yr}$, respectively. If the ridge is running east to west here, i.e., the ridge strike is $90^{\circ}$, the velocities parallel to the spreading directions are 3.4 $\mathrm{cm} / \mathrm{yr}$ and $3.3 \mathrm{~cm} / \mathrm{yr}$. Three or four closely spaced tracks are needed in this area to establish the strike of the ridge and pin down the spreading rate at this critical end of Figure 16.

\section{The Motion of the Antarctica Block Relative to the African Block}

We are now in a position to estimate the motion of the Antarctic block relative to the African block by summing the angular velocity vectors found above to describe the motion of Antarctica relative to the Pacific, the Pacific relative to North America, and North America relative to Africa. The three pole positions and rates found above to describe these motions are listed in the first three columns of Table 5. The angular velocity vectors represented by these angles and rates are transformed into angular velocity in Cartesian coordinates under the headings $1 / 2 a \omega_{x}, 1 / 2 a \omega_{y}, 1 / 2 a \omega_{x}$. The one-half emphasizes that half the spreading rate was used in the calculation, and the factor $a$ (the radius of the earth) allows us to express our results in units of $\mathrm{cm} / \mathrm{yr}$. The first three vectors are then added to obtain the predicted $\omega_{\mathrm{Ant}-\mathrm{Af}}$, and this is transformed back into a pole position and spreading rate. The errors listed in the table were calculated by adding the squares of the errors of each term contributing to the result. More precise values for the three measured angular velocity vectors could reduce this error in $\omega_{\text {Ant-At }}$ to a negligible amount, but there would

TABLE 5. Prediction of Antarctica-Africa Pole from Closure of Africa-North America-Pacific-Antarctica-Africa Circuit

\begin{tabular}{|c|c|c|c|c|c|c|}
\hline & $\begin{array}{l}\text { Latitude, } \\
{ }^{\circ} \mathbf{N}\end{array}$ & $\underset{{ }^{\circ} \mathbf{E}}{\text { Longitude, }}$ & $\begin{array}{l}V_{\max } \\
\mathrm{cm} / \mathrm{yr}\end{array}$ & $\begin{array}{c}\frac{1}{2} a \omega_{x} \\
\mathrm{~cm} / \mathrm{yr}\end{array}$ & $\begin{array}{c}\frac{1}{2} a \omega_{y} \\
\mathrm{~cm} / \mathrm{yr}\end{array}$ & $\begin{array}{c}\frac{1}{2} a \omega_{2}, \\
\mathrm{~cm} / \mathrm{yr}\end{array}$ \\
\hline $\begin{array}{l}\omega_{\text {Am-Af }} \\
\omega_{\text {Pat-Am }} \\
\omega_{\text {Ant-PBo }} \\
\omega_{\text {Ant-Ai }}\end{array}$ & $\begin{array}{r}62 \pm 5 \\
53 \pm 3 \\
-71 \pm 2 \\
-25 \pm 30\end{array}$ & $\begin{array}{rr}-36 & \pm 2 \\
-53 & \pm 5 \\
118 \pm 6 \\
-35 \pm 20\end{array}$ & $\begin{array}{l}1.8 \pm 0.1 \\
4.0 \pm 0.6 \\
5.7 \pm 0.3 \\
1.6 \pm 0.5\end{array}$ & $\begin{array}{r}0.7 \pm 0.1 \\
1.4 \pm 0.3 \\
-0.9 \pm 0.2 \\
1.2 \pm 0.4\end{array}$ & $\begin{array}{r}-0.5 \pm .1 \\
-1.9 \pm .4 \\
1.6 \pm .2 \\
-0.8 \pm .5\end{array}$ & $\begin{array}{r}1.6 \pm 0.1 \\
3.2 \pm 0.5 \\
-5.4 \pm 0.3 \\
-0.6 \pm 0.6\end{array}$ \\
\hline
\end{tabular}


still remain possible systematic errors. Our value for $\omega_{A m-A}$ was determined primarily from data between South America and Africa, and, if North America is moving relative to South America, we must change this rate. If the rate between North America and Africa is more than $1.8 \mathrm{~cm} / \mathrm{yr}$, say $2.2 \mathrm{~cm} / \mathrm{yr}$ as suggested by the data in Figure 9, the pole of $\omega_{\text {Ant-Af }}$ would be shifted northward. If North America is presently splitting apart in Nevada, we need an additional term to correct the rate we found for the Pacific relative to western North America into a rate for the Pacific relative to eastern North America. This additional rate is probably small, and its pole is likely to be somewhere in Canada; such an additional angular velocity vector would shift the resultant pole of $\boldsymbol{\omega}_{\mathrm{Ant}-\mathrm{A} f}$ northward and westward. In addition, any general distortion of the blocks would invalidate the rigidity hypothesis and introduce error in the resultant $\omega_{\text {Ant-Af }}$ found by summing along this path.

The sign of the want-Ar we have found is such that we should expect Africa and Antarctica to be moving apart. The few magnetic profiles available from the Atlantic-Indian rise do not show the characteristic symmetric pattern of the other ridge crests: this has led Vine [1966] to speculate that the Atlantic-Indian rise is an extinct rise. The results here suggest otherwise; the lack of a recognizable magnetic pattern over the crest is then supposedly the result of crossing a highly fractured region of the ridge at angles oblique to the direction of spreading. If more significance than just the sign is given to the value of $\boldsymbol{\omega}_{\mathbf{A} \mathbf{n}-\mathbf{\Delta t}}$, we may expect Africa and Antarctica to be separating about a pole in the South Atlantic Ocean with a maximum half-rate of about $1.5 \mathrm{~cm} / \mathrm{yr}$. Great circles were constructed perpendicular to the strikes of the Malagasy fracture zone and the nearby Prince Edward fracture zone. These two great circles intersect at grazing angles, and a unique pole position could not be determined from their intersection. A pole at $15^{\circ} \mathrm{S}, 15^{\circ} \mathrm{W}$ is compatible with these circles and is within the error limits shown in Table 5; there is no contradiction between the observations of the rise and that predicted by closure. As stated above, there are no magnetic profiles across this rise with which to check the predicted spreading rate, but it is possible to estimate this rate by closure around the triple junction of rises in the center of the Indian Ocean. The mid-Indian Ocean rise between Antarctica and Australia is opening north to south at a rate of about $3.0 \mathrm{~cm} / \mathrm{yr}$ [Le Pichon, 1968], and the Carlsberg ridge is opening more or less north to south at a rate of about $1.5 \mathrm{~cm} / \mathrm{yr}$. The difference between these rates agrees with the value of $1.5 \mathrm{~cm} / \mathrm{yr}$ listed in Table 5 .

If the closure principle demonstrated here is shown to have acceptable precision, we may use rates measured over rises (or across transcurrent faults on land) to predict the velocity difference between the two sides of a trench. It will be interesting to see if properties of trench systems can be correlated with the rate of closing or the angle between the velocity difference of the two sides and the axis of the trench.

\section{Conchusion}

The evidence presented here favors the existence of large 'rigid' blocks of crust. That continental units have this rigidity has been implicit in the concept of continental drift. That large oceanic regions should also have this rigidity is perhaps unexpected. The required strength cannot be in the crust alone; the oceanic crust is too thin for this. We instead favor a strong tectosphere, perhaps $100 \mathrm{~km}$ thick, sliding over a weak asthenosphere. Theoretical justification for a model of this type has been advanced by Elsasser [1967]. In the simple two-dimensional picture of a rise and a trench with a continent between them, we imagine a conveyer-belt process in which the drifting continent need have no great strength. In the model considered here, we may have local hot spots on the rise and faster sinking at some places on the trenches. The crustal blocks should have the mechanical strength necessary to average out irregular driving sources into a uniform motion; the tectosphere should be capable of transmitting even tensile stresses. The crustal block model can possibly explain the median position of most oceanic rises and the symmetry of their magnetic pattern. We assume that the location of the rises is not fixed by some deep-seated thermal source but is determined by the motion of the blocks. Suppose a crustal block is under tension and splits along some line of weakness. The forces that tore it apart continue to act, 
and the blocks move apart creating a void, say, $1 \mathrm{~km}$ wide and $100 \mathrm{~km}$ deep, which is filled with mantle material. As the blocks move farther apart, they split down the center of the most recently injected dike, since this is the hottest and weakest portion between the two blocks. Even if one block remains stationary with respect to the mantle and only one block moves, we will have a symmetric pattern if a new dike is always injected up the center of the most recent dike. If the initial split was entirely within a large continental block, this control of mantle convection by boundary conditions at the top surface will result in a ridge crest with a median position.

Acknowledgments. I thank F. J. Vine for many suggestions during the formative stages of this paper, and R. L. Chase and J. D. Phillips for their careful reading of the manuscript and suggestions for its improvement. I also thank L. R. Sykes for his preprints on the earthquake mechanism solutions, he and D. G. Tobin for an advance copy of their figure of the seismicity of the Juan de Fuca area, and $X$. Le Pichon for pointing out an error in my original analysis of the Pacific-Antarctic ridge.

The computer facilities at Princeton were supported in part by National Science Foundation Grant NSF GP-579. My pleasant summer stay at Woods Hole Oceanographic Institution was supported by Office of Naval Research contract Nonr-4029.

\section{REFERENCES}

Allen, C. R., P. St. Amand, C. F. Richter, and J. M. Nordquist, Relationship between seismicity and geologic structure in the southern California region, Bull. Seismol. Soc. Am., 55, $753,1965$.

Biehler, S., R. L. Kovack, and C. R. Allen, Geophysical framework of northern end of Gulf of California structural province, in Marine $G e$ ology of the Gulf of California, edited by T. H. van Andel and G. G. Shor, American Association of Petroleum Geologists, Tulsa, 1964.

Bullard, E. C., J. E. Everett, and A. G. Smith, The fit of the continents around the Atlantic, Phil. Trans. Roy. Soc. London, Ser. A, 258, 41, 1965.

Davis, T. N., and N. K. Sanders, Alaska earthquake of July 10, 1958; intensity distribution and field investigation of northern epicentral region, Bull. Seismol. Soc. Am., 50, 221, 1960.

Dibblee, T. W., Jr, Evidence for cumulative offset on the San Andreas fault in central and northern California, Bull. Califormia Div. Mines Geology, 190, 375, 1966.

Elsasser, W. M., Convection and stress propagation in the upper mantle, to appear in volume on New Castle Symposium, John Wiley, New York, 1967.

Hamilton, W., and W. B. Myers, Cenozoic tectonics of the western United States, Rev. Geo. phys., 4, 509, 1966.

Heezen, B. C., E. T. Bunce, J. B Hersey, and M. Tharp, Chain and Romanche fracture zones, Deep Sea Res., 11, 11, 1964a.

Heezen, B. C., R. D. Gerard, and M. Tharp, The Vema fracture zone in the equatorial Atlantic, J. Geophys. Res., 69, 733, $1964 b$.

Heezen, B. C., and Marie Tharp, Tectonic fabric of the Atlantic and Indian oceans and continental drift, Phil. Trans. Roy. Soc. London, Ser. A, 258, 90, 1965.

Heirtzler, J. R., Evidence for ocean floor spreading across the ocean basins, in NASA symposium on The History of the Earth's Crust, edited by R. A. Phinney, Princeton University Press, Princeton, 1968.

Heirtzler, J., and X. Le Pichon, Crustal structure of the mid-ocean ridges, 3, Magnetic anomalies over the mid-Atlantic ridge, J. Geophys. Res., 70, 4013, 1965.

Heirtzler, J. R., X. Le Pichon, and J. G. Baron, Magnetic anomalies over the Reykjanes ridge, Deep-Sea Res., 13, 427, 1966.

Hodgson, J. H., and W. Milne, Direction of faulting in certain earthquakes of the north $\mathrm{Pa}$ cific, Bull. Seismol. Soc. Am., 41, 221, 1951.

Le Pichon, X., Sea floor spreading and continental drift, to be published, 1968.

Menard, H. W., Extension of northeastern-Pacific fracture zones, Science, 155, 72, 1967.

Oakeshott, G. B., San Andreas fault in the California Coast Ranges province, Bull. California Div. Mines Geology, 190, 357, 1966.

Phillips, J. D., Magnetic anomalies over the midAtlantic ridge near $27^{\circ} \mathrm{N}$, Science, $157,920,1967$.

Pitman, W. C., III., E. M. Herron, and J. R. Heirtzler, Magnetic anomalies in the Pacific and sea-floor spreading, J. Geophys. Res., $78(6)$, 1968.

Raff, A. D., and R. G. Mason, Magnetic survey off the west coast of North America $40^{\circ} \mathrm{N}$ latitude to $50^{\circ} \mathrm{N}$ latitude, Bull. Geol. Soc. Am., 72, $1251,1961$.

Rusnak, G. A., R L. Fisher, and F. P. Shepard, Bathymetry and faults of Gulf of California, in Marine Geology of the Gulf of California, edited by T. H. van Andel and G. G. Shor, American Association of Petroleum Geologists, Tulsa, 1964.

St. Amand, P., Geological and geophysical synthesis of the tectonics of portions of British Columbia, the Yukon Territory, and Alaska, Bull. Geol. Soc. Am., 68, 1343, 1957.

Stauder, W., The Alaska earthquake of July 10, 1958: Seismic studies, Bull. Seismol. Soc. Am., $50,293,1960$.

Sykes, I. R., Seismicity of the South Pacific Ocean, J. Geophys. Res., 68, 5999, 1963.

Sykes, L. R., Mechanism of earthquakes and na- 
ture of faulting on the mid-oceanic ridges, $J$. Geophys. Res., 72, 2131, 1967.

Sykes, L. R., Seismological evidence for transform faults, sea-floor spreading, and continental drift, in NASA symposium on The History of the Earth's Crust, edited by R. A. Phinney, Princeton University Press, Princeton, 1968a,

Sykes, L. R., Seismicity of the mid-ocean ridge system, to appear in Upper Mantle Committee monograph on the earth's crust and upper mantle, $1968 b$.

Talwani, M., B. C. Heezen, and J. L. Worzel, Gravity anomalies, physiography and crustal structure of the mid-Atlantic ridge, Publ. Bur. Central Seismol. Intern., Ser. A, Trav. Sci., Fasc. शQ, 81, 1961.

Tobin, D. G, and L. R. Sykes, The seismicity and tectonics of the northeast Pacific Ocean (abstract), Trans. Am. Geophys. Union, 48, 204, 1967.

Tocher, D., The Alaska earthquake of July 10, 1958: Movement on the Fairweather fault and field investigation of southern epicentral region, Bull. Seismol. Soc. Am., 60, 267, 1960.

U. S. Naval Oceanographic Office, Microfilm reel of Project Magnet total intensity data, Reel 6, 1965.

Vacquier, V., and R. P. Von Herzen, Evidence for connection between heat flow and the midAtlantic ridge magnetic anomaly, J. Geophys. Res., 69, 1093, 1964.

Vine, F. J., Spreading of the ocean floor: New evidence, Science, 154, 1405, 1966.

Vine, F. J., Magnetic anomalies associated with mid-ocean ridges, in NASA symposium on The History of the Earth's Crust, edited by R. A. Phinney, Princeton University Press, Princeton, 1968.

Wilson, J. T., A new class of faults and their bearing on continental drift, Nature, 207, 343, 1965.

(Received August 30, 1967;

(revised November 30, 1967.) 